\title{
Modern water/rock reactions in Oman hyperalkaline peridotite aquifers and implications for microbial habitability
}

4 Hannah M. Miller ${ }^{\mathrm{a}, *}$, Jürg M. Matter ${ }^{\mathrm{b}, \mathrm{c}}$, Peter Kelemen ${ }^{\mathrm{c}}$, Eric T. Ellison ${ }^{\mathrm{a}}$, Mark E. Conrad ${ }^{\mathrm{d}}$, Noah Fierer $^{\mathrm{e}, \mathrm{f}}$, Tyler Ruchala ${ }^{\mathrm{g}}$, Masako Tominaga ${ }^{\mathrm{g}}$, and Alexis S. Templeton ${ }^{\mathrm{a} *}$

6 a Department of Geological Sciences, UCB 399, University of Colorado, Boulder, CO 80309, 7 USA

$8 \quad{ }^{b}$ Department of Ocean and Earth Science, University of Southampton, UK SO14 3ZH

9 'Lamont-Doherty Earth Observatory of Columbia University, 61 Route 9W, Palisades, NY

10 10964, USA

11 d Earth Sciences Division, MS 70A-4418, E.O. Lawrence Berkeley National Laboratory, 12 Berkeley, CA 94720, USA

13 'Department of Ecology and Evolutionary Biology, CIRES 215,-University of Colorado, 14 Boulder, CO 80309, USA

15 f Cooperative Institute for Research in Environmental Sciences, University of Colorado, Boulder, 16 CO 80309

$17{ }^{\mathrm{g}}$ Department of Geology and Geophysics, Texas A\&M University, College Station, TX 77843, 18 USA

19 *Corresponding author. Tel.:+1 303.492.6174 E-mail address: hannah.miller-1@colorado.edu

$20{ }^{*}$ Co-corresponding author. Tel: +1 303.735.6069 E-mail address:

21 alexis.templeton@,colorado.edu 
Abstract:

23 The Samail ophiolite in Oman is undergoing modern hydration and carbonation of peridotite and may host a deep subsurface biosphere. Previous investigations of hyperalkaline fluids in Oman have focused on fluids released at surface seeps, which quickly lose their reducing character and precipitate carbonates upon contact with the $\mathrm{O}_{2} / \mathrm{CO}_{2}$-rich atmosphere. In this work, geochemical analysis of rocks and fluids from the subsurface provides new insights into the operative reactions in serpentinizing aquifers. Serpentinite rock and hyperalkaline fluids $(\mathrm{pH}>10)$, which exhibit millimolar concentrations of $\mathrm{Ca}^{2+}, \mathrm{H}_{2}$ and $\mathrm{CH}_{4}$, as well as variable sulfate and nitrate, were accessed from wells situated in mantle peridotite near Ibra and studied to investigate their aqueous geochemistry, gas concentrations, isotopic signatures, mineralogy, Fe speciation and microbial community composition.

33 The bulk mineralogy of drill cuttings is dominated by olivine, pyroxene, brucite, serpentine and magnetite. At depth, Fe-bearing brucite is commonly intermixed with serpentine, whereas near the surface, olivine and brucite are lost and increased magnetite and serpentine is detected. Micro-Raman spectroscopy reveals at least two distinct generations of serpentine present in drill cuttings recovered from several depths from two wells. Fe K-edge x-ray absorption near-edge spectroscopy (XANES) analysis of the lizardite shows a strong tetrahedral Fe coordination, suggesting a mixture of both Fe(II) and Fe(III) in the serpentine. Magnetite veins are also closely associated with this second generation serpentine, and $2-10 \mu \mathrm{m}$ magnetite grains overprint all minerals in the drill cuttings. Thus we propose that the dissolved $\mathrm{H}_{2}$ that accumulates in the subsurface hyperalkaline fluids was evolved through low temperature oxidation and hydration of relict olivine, as well as destabilization of pre-existing brucite present in the partially serpentinized dunites and harzburgites. In particular, we hypothesize that Fe-bearing brucite is currently reacting with dissolved silica in the aquifer fluids to generate late-stage magnetite, additional serpentine and dissolved $\mathrm{H}_{2}$.

47 Dissolved $\mathrm{CH}_{4}$ in the fluids exhibits the most isotopically heavy carbon in $\mathrm{CH}_{4}$ reported in the 48 literature thus far. The $\mathrm{CH}_{4}$ may have formed through abiotic reduction of dissolved $\mathrm{CO}_{2}$ or through biogenic pathways under extreme carbon limitation. The methane isotopic composition may have also been modified by significant methane oxidation. 16S rRNA sequencing of DNA recovered from filtered hyperalkaline well fluids reveals an abundance of Meiothermus, Thermodesulfovibrionaceae (sulfate-reducers) and Clostridia (fermenters). The fluids also contain candidate phyla OP1 and OD1, as well as Methanobacterium (methanogen) and Methylococcus sp. (methanotroph). The composition of these microbial communities suggests that low-temperature hydrogen and methane generation, coupled with the presence of electron acceptors such as nitrate and sulfate, sustains subsurface microbial life within the Oman ophiolite. 


\section{Introduction}

The Samail ophiolite in the Sultanate of Oman, the largest and best exposed ophiolite sequence on Earth, is well-suited to the study of low temperature serpentinization, which is the aqueous alteration of ultramafic rocks. Over $15,000 \mathrm{~km}^{3}$ of peridotite is currently undergoing low temperature hydration and oxidation (Barnes et al., 1978; Neal and Stanger, 1983; Neal and Stanger, 1985; Clark and Fontes, 1990; Kelemen and Matter, 2008; Kelemen et al., 2011; Streit et al., 2012; Paukert et al., 2012). Modern serpentinization is inferred from the distribution of hyperalkaline seeps that release hyperalkaline fluids rich in $\mathrm{H}_{2}$ and $\mathrm{CH}_{4}$, and poor in dissolved inorganic and organic carbon. However, the water/rock reaction pathways giving rise to $\mathrm{H}_{2}$ and methane formation at near-surface temperatures are not known. Moreover, no studies have yet explored whether the active hydrogeochemical system hosts a subsurface biosphere.

In Oman, the mantle peridotite consists of olivine, orthopyroxene, and serpentine, with trace amounts of calcic pyroxene, chromite, and Fe-oxides (Hanghøj et al., 2010). The mantle peridotite is $30-70 \%$ serpentinized (Boudier et al., 2010) and variably carbonated. Some serpentinization occurred during hydrothermal circulation when the ophiolite was situated at an oceanic spreading ridge, some during thrust emplacement of the ophiolite over pelagic and continental margin sediments, some during late Cretaceous sub-aerial weathering and a subsequent marine transgression, and some during ongoing water/rock reactions (Hanghøj et al., 2010; Kelemen et al., 2011). The proportions and spatial distribution of serpentine and other secondary minerals formed during these different events are unclear. Completely unaltered peridotite is not observed in outcrop in Oman, but the least altered samples are found in deep canyons, whereas the most serpentinized outcrops are in areas of low relief (Kelemen et al., 2011). The peridotite also undergoes carbonation reactions as evidenced by modern carbonate vein and terrace dates (Clark and Fontes, 1990; Kelemen and Matter, 2008; Mervine et al., 2014) which indicate temperatures of formation from $30-60^{\circ} \mathrm{C}$ (Kelemen et al., 2011; Streit et al., 2012).

An active hydrological system drives present-day serpentinization and other alteration processes occurring in the subsurface. Groundwater circulation in the peridotite aquifer is controlled by fissure and fracture hydraulic conductivity. Near-surface fissures (perhaps extending to $\sim 50$ meters depth) accommodate most of the groundwater flow with a hydraulic conductivity of $10^{-7}$ $\mathrm{m} / \mathrm{s}$ (Dewandel et al., 2005). The origins of this shallow, hydraulically active zone are not clear, but are probably due to meteoric weathering. The peridotite aquifer contains a network of fractures that began to develop when the ophiolite was hydrothermally altered at the mid-ocean ridge, $\sim 95$ million years ago during the Middle Cretaceous (Coleman, 1981). The fractures in the peridotite host serpentine and carbonate veins (Dewandel et al., 2005). Hyperalkaline surface seeps generally discharge at the contact between the mantle and overlying crustal rocks, and along the basal thrust plane of the ophiolite sequence. They release high $\mathrm{pH}$ fluids $(>11)$ rich in $\mathrm{Ca}^{2+}, \mathrm{OH}^{-}, \mathrm{H}_{2}$, and $\mathrm{CH}_{4}$. The surrounding mineralogy is dominated by carbonates that precipitated when the carbon deprived fluids mixed with atmospheric $\mathrm{CO}_{2}(\mathrm{Kelemen}$ and Matter, 2008; Kelemen et al., 2011; Paukert et al., 2012; Chavagnac et al., 2013; Chavagnac et al., 2013). 
The origin of dissolved $\mathrm{H}_{2}$ and $\mathrm{CH}_{4}$ in Oman are enigmatic. Currently, there is no evidence for modern hydrothermal activity at temperature greater than $200^{\circ} \mathrm{C}$ of water/rock reactions in the peridotite aquifer, which would correspond to a depth of $\sim 8 \mathrm{~km}$ based on a geothermal gradient of $25^{\circ} \mathrm{C} / \mathrm{km}$. Although serpentinization processes have been extensively studied at temperatures $>120^{\circ} \mathrm{C}$, the mineral assemblages and alteration processes leading to formation of dissolved $\mathrm{H}_{2}$ and $\mathrm{CH}_{4}$ during serpentinization at lower temperatures are poorly constrained.

Serpentinization leads to the evolution of hydrogen through hydration and the oxidation of reduced iron species found in olivine and pyroxenes. For typical mantle olivine with molar $\mathrm{Mg} /(\mathrm{Mg}+\mathrm{Fe})=0.9$, a simplified reaction above $200^{\circ} \mathrm{C}$ might be:

$$
\begin{gathered}
\mathrm{Mg}_{1.8} \mathrm{Fe}_{0.2} \mathrm{SiO}_{4}+1.37 \mathrm{H}_{2} \mathrm{O}=0.5 \mathrm{Mg}_{3} \mathrm{Si}_{2} \mathrm{O}_{5}(\mathrm{OH})_{4}+0.3 \mathrm{Mg}(\mathrm{OH})_{2} \\
+0.067 \mathrm{Fe}_{3} \mathrm{O}_{4}+0.067 \mathrm{H}_{2}
\end{gathered}
$$

(e.g. Equation 1; Frost, 1985; McCollom and Bach, 2009). Such water/rock reactions produce fluids rich in $\mathrm{H}_{2}$. These fluids also commonly contain abundant dissolved $\mathrm{CH}_{4}$, which may form abiogenically as the result of Fischer-Tropsch Type or Sabatier reactions (Horita and Berndt, 1999; Etiope et al., 2013), or biologically via methanogenesis (Balch et al., 1979; Sleep et al., 2004).

Hydrogen generation during serpentinization has been modeled from $8-400^{\circ} \mathrm{C}$ (McCollom and Bach, 2009; Okland et al., 2012; Klein et al., 2013). Experimentally produced $\mathrm{H}_{2}$ has been generated from $0-100^{\circ} \mathrm{C}$ (Stevens and McKinley, 1995; Anderson et al., 1998; Stevens and McKinley, 2000; Neubeck et al., 2011; Okland et al., 2012; Mayhew et al., 2013) Comparisons of model and experimental results often yield conflicting results, perhaps because of assumptions included in models. For example, McCollom and Bach (2009) utilize reaction path models to simulate water-rock reactions and resulting mineral assemblages, but they are constrained by the lack of existing thermodynamic data for $\mathrm{Mg}$ :Fe solid solutions, the incorporation of $\mathrm{Fe}(\mathrm{III})$ into secondary silicates, and the lack of data on mineral compositions that form at low temperature. Also, models assume the reactions have reached equilibrium, and it is unlikely that lowtemperature laboratory experiments are fully equilibrated. Thus, detailed analysis of field samples from low-temperature serpentinizing environments is required to ground-truth modeling efforts.

There is also a lack of data on the detection or characterization of microorganisms in Oman's hyperalkaline aquifers. The high concentrations of $\mathrm{H}_{2}$ and $\mathrm{CH}_{4}$ in the hyperalkaline fluids provide electron donors that could be utilized by subsurface chemolithoautotrophic life, which could contribute to carbon cycling in the subsurface (Stevens and McKinley, 1995; Sleep et al., 2004, p.2005; Nealson et al., 2005; Mayhew et al., 2013; Klein et al., 2015). The search for microbial life in other serpentinizing environments has primarily been focused on sequencing the 16S rRNA gene from easily accessible surface springs as windows into the subsurface (Neal and Stanger, 1983; Abrajano et al., 1990; Bruni et al., 2002; Meyer-Dombard et al., 2015; Woycheese et al., 2015), although recent work by Postec et al. (2015) isolated DNA from carbonate chimneys from a low-temperature hydrothermal field. However, all these studies were limited to surface samples collected in oxygenated environments, which allows aerobic 
organisms to flourish. It is unclear if the microbes inhabiting the surface seeps are similar to

150 those active in the anaerobic subsurface.

This study was designed to assess low temperature serpentinization processes in a peridotite aquifer in Oman and to determine what types of microbial life are hosted in the subsurface. We 154 sampled hyperalkaline, $\mathrm{H}_{2-}, \mathrm{CH}_{4}$-rich fluids from 10-300 $\mathrm{m}$ depth in peridotite and studied their 155 geochemistry, gas concentrations and isotopic signatures. We integrated these data with 156 mineralogical and spectroscopic analysis of mineral chips recovered from depth within two 157 peridotite wells to elucidate the oxidation state, mineralogy, and extent of serpentinization of the 158 rocks in contact with deep subsurface fluids. Magnetic hysteresis analyses on downhole bulk 159 rock samples augment these geochemical and mineralogical analyses by providing the 160 distribution of different rock magnetic properties within drilled sections, thereby suggesting 161 possible zonation in the serpentinization process. Geochemical data were complemented by high 162 throughput $16 \mathrm{~S}$ rRNA sequencing of DNA recovered from the well fluids to identify microbial 163 organisms present in the fluid. These data provide the first insights into the modern water/rock 164 reactions in a hyperalkaline Oman aquifer, and the potential coupling between geochemical and 165 microbiological processes during low-temperature serpentinization. 


\subsection{Field methods}

The Ministry of Water Resources of the Sultanate of Oman drilled numerous wells into peridotite ( $\sim 300$ meters deep) to investigate water resources for the region. Water samples and drill cuttings were obtained from wells NSHQ14 and NSHQ04 in a peridotite plain in the Samail ophiolite, Oman (Figure 1). NSHQ04 is near a north/south trending fault, with gabbro to the west and mixed dunite and gabbro lenses cut by pyroxenite dikes to the east. NSHQ14 is several kilometers from the crust-mantle boundary; the surrounding rocks are mainly harzburgite with meter-scale dunite bands.

In January 2014, a shallow submersible pump was used to collect water from 18 meters depth in both NSHQ04 and NSHQ14, and a stainless steel bailer was used to collect water from 260 meters in well NSHQ14. Water samples containing dissolved gases were collected in sterile syringes and injected into $\mathrm{N}_{2}$-purged vials and later used for headspace gas analysis. The vials were acid washed, autoclaved and baked at $400^{\circ} \mathrm{C}$ in a muffle furnace prior to field work. Samples for ICP-MS analysis were filtered with $0.2 \mu \mathrm{m}$ Millipore filters and acidified in the field with concentrated nitric acid to $\sim \mathrm{pH} 2$. The fluid $\mathrm{pH}$, temperature, and conductivity were measured with a conductivity meter (YSI Model\#85/10) while $\mathrm{pH}$ was measured with a MettlerToledo SevenGo2 $\mathrm{pH}$ meter calibrated with reference standards of $\mathrm{pH} 12.46,10.01$, and 7 .

Fluids ( $\sim 5-10 \mathrm{~L})$ from the wells were pumped and filtered through $0.2 \mu \mathrm{m}$ Sterivex inline filters to recover biomass for DNA extraction. Filters were transported frozen in liquid nitrogen and stored in a $-70^{\circ} \mathrm{C}$ freezer until extraction.

We also obtained drill cuttings (rock chips recovered during drilling) of the wells from 262, 140, 70, and 17 meters depth at NSHQ14 and from 303, 180, and 120 meters depth at well NSHQ04. These were mounted in epoxy and prepared as $30 \mathrm{~mm}$ thick polished thin sections for analysis.

\section{3}

\subsection{Laboratory methods}

Major cations $\left(\mathrm{Mn}^{2+}, \mathrm{Fe}^{2+}, \mathrm{Mg}^{2+}, \mathrm{Ca}^{2+}, \mathrm{Al}^{3+}\right), \mathrm{SiO}_{2}$, and trace elements $(\mathrm{Ni}, \mathrm{As}, \mathrm{Se}, \mathrm{Cu}, \mathrm{Cd}, \mathrm{Zn}$ $\mathrm{Co}, \mathrm{Cr}$ ) were analyzed on field-acidified and filtered well waters using Inductively Coupled Plasma-Mass Spectrometry (ICP-MS) on a ThermoScientific X Series 2. Major anions (F', $\mathrm{Cl}^{-}$, $\mathrm{Br}^{-}, \mathrm{NO}_{3}{ }^{-}, \mathrm{PO}_{4}{ }^{3-}, \mathrm{SO}_{4}{ }^{2-}$ ) were analyzed using Ion Chromatography (IC) on a Dionex IC25 with an IonPac column and a $9 \mathrm{mM}$ sodium carbonate eluent. Water samples were collected in acidwashed, autoclaved, and ashed organic free vials and sent to NASA Ames Research Center to measure low weight molecular organic acids on a Shimadzu Prominence LC20AT highdetector and a flow rate of $1 \mathrm{~mL}$ per minute.

Drill cuttings were powdered with a mortar and pestle and then x-ray diffraction (XRD) data were obtained using $\mathrm{CuK} \alpha$ radiation $(\lambda=1.5418 \AA)$ in the range $15-65^{\circ} 2 \theta$ using a Bruker D2 Phaser operated at $30 \mathrm{kV}$ and $10 \mathrm{~mA}$. A Lynxeye 1D detector with a step size of $0.02^{\circ}$ and collection time of $1 \mathrm{~s}$ per step were employed. The XRD spectra were semi-quantitatively fit using the Bruker DiffracEva program and results were compared to the RRUFF database (Downs 2006). 
To determine $\mathrm{H}_{2}$ and $\mathrm{CH}_{4}$ concentrations (detection limit of $10 \mathrm{ppm}$ and analytical error of 5\%) in the gases exsolved from the well fluids, we used a SRI 8610C gas chromatograph (GC) with a $2 \mathrm{~m}$ by $1 \mathrm{~mm}$ ID micropacked ShinCarbon ST column with $\mathrm{N}_{2}$ as the carrier gas. $0.5 \mathrm{~mL}$ of gas was sampled from the headspace of serum vials sealed with blue rubber stoppers and was injected into a sampling port on the GC. $\mathrm{H}_{2}$ was measured with a thermal conductivity detector (TCD), and a flame ionization detector (FID) was concurrently used to measure $\mathrm{CH}_{4}$.

Stable isotope analyses were conducted at the Center for Isotope Geochemistry at the Lawrence Berkeley National Laboratory. The isotopic compositions of $\mathrm{H}_{2}$ and $\mathrm{CH}_{4}$ were analyzed using a Thermo Scientific GC Trace Gas Ultra system connected to a Thermo Scientific Delta V Plus Mass Spectrometer (IRMS). Gas samples were injected into a 6-port valve (the loop size varied from $5 \mathrm{~L}$ to $250 \mathrm{~L}$ depending on the concentration of the analyte in the sample) bypassing the inlet of the GC. After flushing with at least 3 times the volume of the loop, the sample was injected into the GC where the gases were separated chromatographically on an HP-molesieve fused silica capillary column ( $30 \mathrm{~m} \times 0.320 \mathrm{~mm})$. For $\mathrm{H}_{2}$, after the samples went through the GC, they were passed through a combustion furnace at room temperature and then into the IRMS. Reproducibility of these analyses is $\pm 2.5 \%$ ( $1 \mathrm{~s}$ ), as determined by repeated analyses of a laboratory gas standard. Carbon isotope ratios of $\mathrm{CH}_{4}$ were analyzed using the same system with with the combustion furnace (a capillary ceramic tube loaded with $\mathrm{Ni}, \mathrm{Cu}$, and $\mathrm{Pt}$ wires) set at $1030{ }^{\circ} \mathrm{C}$ where the $\mathrm{CH}_{4}$ was converted to $\mathrm{CO}_{2}$. Produced water was removed, and the carbon isotope ratio of the resulting $\mathrm{CO}_{2}$ was measured in the IRMS. The reproducibility of these analyses is $\pm 0.2 \%$. For hydrogen isotopes of $\mathrm{CH}_{4}$, the sample was passed through a pyrolysis furnace at $1450{ }^{\circ} \mathrm{C}$ and the resulting $\mathrm{H}_{2}$ gas measured with the IRMS. The reproducibility of these analyses is $\pm 5 \%$.

Samples with 10-100 micrograms calcite were reacted with $100 \% \mathrm{H}_{3} \mathrm{PO}_{4}$ at $90^{\circ} \mathrm{C}$ and then used for both carbon and oxygen isotope analyses $\left(\delta^{13} \mathrm{C}\right.$ and $\left.\delta^{18} \mathrm{O}\right)$, which were determined using a GV IsoPrime mass spectrometer with Dual-Inlet and MultiCarb systems in the Center for Stable Isotope Biogeochemistry (CSIB) at Department of Integrative Biology, University of California at Berkeley. Several replicates of one international standard NBS19, and two lab standards $\mathrm{CaCO}_{3}$-I \& II were measured along with samples for each run. The overall external analytical precision is about $+0.05 \%$ for $\delta^{13} \mathrm{C}$ and about $+0.07 \%$ for $\delta^{18} \mathrm{O}$.

The isotopic compositions of the water samples were measured using CIG's Los Gatos Research Liquid Water Isotope Analyzer (LWIA). $1 \mathrm{ml}$ of each sample was loaded into $2 \mathrm{ml}$ vials. Using an auto sampler, each sample was injected into the LWIA 8 times where the data for the first 3 injections were discarded and the data for the remaining 5 injections averaged to give the raw isotope values. The data were then compared to a series of 3 standards bracketing the expected isotopic values of the samples analyzed and run multiple times throughout the run. The reproducibility of these analyses based on repeated analyses of the standards is better than $\pm 1 \%$ o for $\delta \mathrm{D}$ and $\pm 0.2 \%$ for $\delta^{18} \mathrm{O}$.

\subsection{Microscale analytical techniques}


Synchrotron-based hard X-ray measurements of Fe K-edge micro-X-ray absorption near edge spectra $(\mu \mathrm{XANES})$ were conducted at Beamline 2-3 at the Stanford Synchrotron Radiation Lightsource (SSRL). The incident energy was selected with a Si (111) double crystal monochromator with the SPEAR accelerator ring containing $\sim 150-200 \mathrm{~mA}$ at $3.0 \mathrm{GeV}$. The beam was focused to approximately 2 by $2 \mu \mathrm{m}$ using Kirkpatrick Baez mirrors. Data were collected at the $\mathrm{Fe} \mathrm{K}$-edge using a $\mathrm{Fe}^{0}$ foil calibration of $7112 \mathrm{eV}$ with a single-element Vortex detector capable of reading several million counts per second.

Fe K-edge mapping was conducted at 8 energies $(7123,7126,7128,7129,7130,7131,7133$ $\mathrm{keV}$ ) chosen to maximize the differences in normalized intensity between representative XANES (Mayhew et al., 2011; Mayhew et al., 2013). These data were coupled with an $11 \mathrm{keV}$ map of trace element distribution to identify unique areas in the sample. Principle Components Analysis (PCA) on these multiple energy XRF maps were used to identify the location of unique Fe species in the map area using Sam's Microprobe Analysis Kit (SMAK). We then collected representative $\mu$ XANES spectra from those spots and employed PCA to identify key end member $\mu$ XANES spectrum that represent the unique chemical forms of Fe in each sample. Finally, multiple-energy maps were fit with the fluorescence intensities of each end member mXANES spectra to show the distribution of Fe-bearing minerals in complex reacted and unreacted samples.

XANES were normalized with Sam's Interface for XAS Package (SIXPACK). XANES spectra were collected from a range of $6882-7152 \mathrm{eV}$. To qualitatively determine Fe speciation and mineralogy, spectra were fit from 7110 to $7150 \mathrm{eV}$ using least squares fitting of Fe model compounds (in SIXPACK) calibrated using the first inflection of a $\mathrm{Fe}^{0}$ foil at $7112 \mathrm{eV}$ (Mayhew et al., 2011). We also collected the pre-edge (7108-7118eV) region with a step size of $0.1 \mathrm{eV}$ and dwell time of 3 seconds and analyzed the pre-edge employing protocols by Andreani et al. (2013) and Wilke et al. (2001) to determine the ratio of $\mathrm{Fe}^{2+} / \mathrm{Fe}^{3+}$ in the various generations of serpentine.

Beamline 4-1 at SSRL was used to collect bulk Fe K-edge spectra for seven powdered well chip samples. A Si (220) $\phi=0$ monochromator was used and X-ray absorption spectra (XAS) were collected on a Lytle detector. A Fe foil standard was used and calibrated to $7112 \mathrm{eV}$. Duplicate spectra were collected and averaged for XANES scanning from a range of $6882-7082 \mathrm{eV}$ with a step size of 10 points, then from 7092 to 7520 with a 0.35 step size.

Quantum Design MPMS Superconducting Quantum Interface Device (SQUID) magnetometer with the magnetic moment resolution of $10^{-8} \mathrm{emu}$ at Department of Physics and Astronomy at Michigan State University was used to analyze bulk rock powder samples to determine magnetic hysteresis parameters. A total of 7 samples with various weights $(40-259 \mathrm{mg})$ are measured over the range of $\pm 5 \mathrm{~T}$ at $300 \mathrm{~K}$.

Micro-Raman spectra and hyperspectral maps for well rock chip samples were collected using a Horiba LabRAM HR Evolution Raman spectrometer equipped with a $532 \mathrm{~nm}$ frequency-doubled Nd:YAG laser (Laser Quantum, Torus $532+$ mpc3000) coupled to an Olympus BXFM optical microscope. The laser beam was focused through a 50x objective lens, yielding a spatial resolution of $\sim 2 \mu \mathrm{m}$. A 600 lines $/ \mathrm{mm}$ grating and adjustable confocal pinhole $(100 \mu \mathrm{m}-200 \mu \mathrm{m})$ 
was used to give a spectral resolution full width at half maximum (FWHM) of $4.5-8.4 \mathrm{~cm}^{-1}$. Spectra were collected from $20-1200 \mathrm{~cm}^{-1}$ using a Si-based CCD detector (1024 x 256 pixels).

302 The spectrometer was calibrated using the $520 \mathrm{~cm}^{-1}$ Raman peak of Si daily prior to analysis. Spectral data were corrected for instrumental artifacts and baseline-subtracted using a polynomial fitting algorithm in LabSpec 6 (Horiba Scientific). For the Raman microspectroscopy analyses, the drill cuttings from each depth in NSHQ14 and NSHQ04 were analyzed by generating hyperspectral maps of representative areas in the thin sections, using Multivariate Curve Resolution-Alternating Least Squares (MCR-ALS) and non-negativity constraints on scores and loadings to determine the main spectral components present, then collecting spot Raman spectra to verify the components, and fitting the hyperspectral data set with the end member spectra to generate component maps.

Quantitative chemical analysis of serpentine was performed using the electron microprobe laboratory at the University of Colorado at Boulder on the JEOL JXA-8600 equipped with 4 wavelength-dispersive spectrometers, and a PGT energy-dispersive spectrometer. Spot analyses of polished thin sections were performed at a current of $10 \mathrm{nA}$, accelerating voltage of $15 \mathrm{keV}$, and beam diameter of $10 \mu \mathrm{m}$ to avoid destroying the hydrated serpentine sample to analyze the major element compositions of $\mathrm{Si}, \mathrm{Al}, \mathrm{Mg}, \mathrm{Na}, \mathrm{Ca}, \mathrm{Cr}, \mathrm{K}, \mathrm{Fe}, \mathrm{Mn}$, and $\mathrm{Ti}$, using natural standards.

TGA measurements were taken in a NETZSCH STA 449 F1 Jupiter. Between 60 and $110 \mathrm{mg}$ of sample in an alumina crucible and a blank alumina crucible were heated in Argon up to $1000^{\circ} \mathrm{C}$ at a ramp rate of $10 \mathrm{Kelvin}$ per minute. The crucibles were then held at $1000^{\circ} \mathrm{C}$ for one hour, at which point data collection stopped and the furnace cooled. The derivatives of the data were determined using NETZSCH Proteus.

\section{$2.416 S$ rRNA sequencing}

The microbial analyses were conducted as described previously (Bowers et al., 2013; Emerson et al., 2015). DNA was extracted from one quarter of each of the filter samples using the MoBio PowerSoil kit. The V4-V5 region of the 16S rRNA gene was PCR amplified in triplicate reactions using the $515 \mathrm{f} / 806 \mathrm{r}$ primer pair. The primers contained the appropriate Illumina adapters and the reverse primer contains a 12-bp error-correcting barcode unique to each sample. The triplicate reactions were composited, amplicon concentrations were determined using the PicoGreen dsDNA assay, and the amplicons from all samples were pooled together in equimolar concentrations. Sequencing was conducted on an Illumina MiSeq at the University of Colorado Genomics Core Facility following the $2 \times 250$ bp paired-end protocol. Quality filtering of reads and processing of the reads was conducted as described in Barberán et al. (2015). After demultiplexing, reads were quality filtered at an equivalent sequencing depth (6000 reads per sample) and clustered into phylotypes using the UPARSE pipeline (Edgar, 2013). Reads were assigned to phylotypes at the $\geq 97 \%$ sequence similarity threshold and phylotype taxonomy was determined using the RDP classifier with a confidence threshold of 0.5 (Wang et al., 2007) trained on the Greengenes 13_8 database (McDonald et al., 2012). Multivariate statistical analysis was performed in $\mathrm{R}$, a software environment for statistical computing and graphics ( $\mathrm{R}$ Development Core Team, 2008). 


\subsection{Aqueous geochemistry of wells}

348

Fluids were collected from two wells drilled into peridotite, NSHQ14 (up to a depth of 260m) and NSHQ04 (up to a depth of $50 \mathrm{~m}$, below which the well is collapsed). Minimum concentrations of dissolved $\mathrm{H}_{2}$ and $\mathrm{CH}_{4}$ were determined by GC. For NSHQ14 at 262m, some gas was lost from the fluids during the transfer from the bailer sampler to gas-tight vials due to rapid exsolution. The calculated dissolved $\mathrm{H}_{2}$ concentrations range from 0.18 to $0.67 \mathrm{mM} \mathrm{H}_{2}$, and the methane concentrations range from 0.17 to $1.44 \mathrm{mM}$ (Table 1).

The fluids in both wells are hyperalkaline: NSHQ14 has a pH of 11.5 and NSHQ04 has a pH of 10.6. Major cation and anion analysis for fluids reveals $>6 \mathrm{mM} \mathrm{Ca}^{2+}, \geq 0.005 \mathrm{mM} \mathrm{Mg}^{2+}$, and $6.75-$ $12.30 \mathrm{mM} \mathrm{Na}^{+}$(Table 1). Low molecular weight organic acids (lactate, acetate, formate, propionate, butyrate and valerate) are below detection limits of $\sim 5.0 \mu \mathrm{M}$; thus, there is low dissolved organic carbon in the fluid. Dissolved inorganic carbon (DIC) levels for samples collected from these wells in 2012 were 0.078-0.391 mM (Paukert et al., 2012). Both wells contain high concentrations of $\mathrm{Cl}^{-}(>20 \mathrm{mM})$, which are almost two orders of magnitude higher than the $0.35 \mathrm{~m} \mathrm{M} \mathrm{Cl}^{-}$present in Oman rainwater (Weyhenmeyer, 2000; Paukert et al., 2012). The well fluids contain $0.05-0.48 \mathrm{mM} \mathrm{SO}_{4}{ }^{2-}$ and $0.012-0.022 \mathrm{mM} \mathrm{NO}_{3}{ }^{-}$. The trace element chemistry of the wells is similar; $\mathrm{Ni}$ and $\mathrm{Cr}$ are the most abundant metals (average of 0.15 and $0.18 \mu \mathrm{M}$, respectively. The only notable difference is NSHQ14 at $262 \mathrm{~m}$ has more $\mathrm{Zn}(0.139 \mu \mathrm{M}$ versus $\sim 0.03 \mu \mathrm{M}$ ) than the other depths.

The fluids in the peridotite wells exhibit similar $\mathrm{pH}$ and aqueous geochemistry to surface alkaline springs previously sampled in Oman (Paukert et al., 2012); however, the NSHQ14 and NSHQ04 well fluids contain more $\mathrm{Ca}^{2+}, \mathrm{Cl}^{-}, \mathrm{NO}_{3}{ }^{-}$and generally $\mathrm{SO}_{4}{ }^{2-}$. The dissolved silica concentrations are $\sim 0.01 \mathrm{mM} \mathrm{SiO}_{2(\mathrm{aq})}$ versus the $0.04 \mathrm{mM}$ found in the surface seeps.

Oxidation-reduction potential (ORP) values were measured during the January 2012 field season. NSHQ14 fluids exhibit much higher ORP values $(-31.6 \mathrm{mV})$ near the surface at 18 meter, whereas the fluids at $260 \mathrm{~m}$ are highly reducing $(-597.3 \mathrm{mV})$. The ORP value for fluids collected from NSHQ04 at 70 meters was $-103.4 \mathrm{mV}$.

\subsection{Isotopic composition of fluids, dissolved gases, and carbonates}

The $\delta \mathrm{D}$ values of dissolved $\mathrm{H}_{2}$ are very low (-680\% and $-686 \%$ for NSHQ04 and NSHQ14 respectively, Table 2). The $\delta^{18} \mathrm{O}$ of the well waters are $-3.0 \%$ and $0.7 \%$ and the $\delta \mathrm{D}$ values are $15 \%$ for NSHQ04 and 2\% for NSHQ14. If the dissolved $\mathrm{H}_{2}$ formed in isotopic equilibrium with the water, we calculate a temperature of formation of $\sim 50^{\circ} \mathrm{C}$ using the theoretical geothermometer developed by Bottinga (1969). The $\delta \mathrm{D}$ values of $\mathrm{CH}_{4}$ are also low, $-205 \%$ and $232 \%$ for NSHQ04_18m and NSHQ14_262m, respectively. In contrast, the $\mathrm{CH}_{4}$ is strongly enriched in ${ }^{13} \mathrm{C}\left(\delta^{13} \mathrm{C} \mathrm{CH}_{4}\right.$ for NSHQ04_18m is $+2.4 \%$; NSHQ14_262m is $+3 \%$ ) (Table 2). These $\delta^{13} \mathrm{C} \mathrm{CH}_{4}$ and $\delta \mathrm{D} \mathrm{CH}_{4}$ values from Oman subsurface fluids are notably higher than previously defined isotopic fields for thermogenic, biogenic, and abiotic methane (Figure 2). The carbonate found in the drill cuttings $\delta^{13} \mathrm{C}_{\mathrm{VPDB}}$ ranges from -1.48 to $-7.05 \%$ while the $\delta^{18} \mathrm{O}_{\mathrm{VPDB}}$ ranges from -7.73 to $-11.49 \%$ (Table 3 ). The carbonate concentrations in the rock were low and not quantified. 


\subsection{Mineralogy of drill cuttings}

388 Bulk powder XRD spectra are similar between the two wells. They are dominated by lizardite and enstatite and contain magnetite near the surface (Figure 3A,B). In the drill cuttings at 70, 140 , and $262 \mathrm{~m}$ from NSHQ14, there is a brucite peak at 18.820 , but not at the shallow $17 \mathrm{~m}$. NSHQ04 drill cutting XRD spectra also contain a brucite peak at depth (180 and 303m), but not at $120 \mathrm{~m}$. There is a magnetite peak at $35.52 \theta$ in the NSHQ14 drill cuttings at 17 and $70 \mathrm{~m}$ and in the NSHQ04 drill cuttings at 120 and $180 \mathrm{~m}$.

Microscale mineralogical structure and chemistry of drill cuttings were determined by a combination of petrologic observations, Raman microspectroscopy, Fe K-edge XANES spectroscopy and electron microprobe analyses. Olivine, diopside, enstatite, chromite, magnetite, brucite, and two-three different generations of serpentine, both chrysotile and lizardite, were detected in the drill cuttings of both wells using Raman microspectroscopy (Figure 4). Brucite and olivine are not detected in the drill cuttings closer to the surface, approximately $<120 \mathrm{~m}$. The NSHQ14 drill cuttings become increasingly serpentinized as they approach the surface, showing decreasing relict olivine with proximity to the surface and increasing serpentine (Figure 5). The NSHQ04 drill cuttings also show increased serpentine closer to the surface. There are visually more pyroxenes present in NSHQ04, both diopside and enstatite (Figure 6), and they appear to be partially fractured and altered (lower left corner of Figure 5). Drill cuttings from both wells have magnetite veins and grains $(\sim 5 \mu \mathrm{m})$ between 17-120 meters deep.

The Raman maps demonstrate that the drill cutting mineralogy is dominated by two to three generations of serpentine. Although chrysotile, lizardite, and antigorite can be identified by Raman spectroscopy from their varying peak positions (Rinaudo et al., 2003; Groppo et al., 2006; Petriglieri et al., 2015), differences in peak position are relatively small and can be obscured by large crystal orientation effects on the relative peak intensities. Furthermore, the effects of varying $\mathrm{Mg} /(\mathrm{Mg}+\mathrm{Fe})$ and $\mathrm{Fe}^{3+} / \mathrm{Fe}_{\mathrm{T}}$ on the Raman spectra for the serpentine polytypes are not yet well quantified. Thus, it is difficult to determine the polymorphs of serpentine with certainty when just looking at the fingerprint region from $90-1600 \mathrm{~cm}^{-1}$. By mapping the serpentine in both the fingerprint region of $90-1600 \mathrm{~cm}^{-1}$ and in the more diagnostic O-H stretching region of $3400-3800 \mathrm{~cm}^{-1}$, different regions of serpentine have been identified as chrysotile and lizardite (Figure 7C).

Crosscutting relationships reveal distinct generations of serpentine. NSHQ14 at 262 meters contains two generations of lizardite with an older lizardite (14-gen1) crosscut by a younger lizardite (14-gen2) (Figure 4). NSHQ04 at 180 meters has a complex alteration history with a first generation of chrysotile (04-gen1) overprinted by a younger second generation of chrysotile (04-gen2). Brucite is intermixed with third generation lizardite (04-gen3). The intermixed lizardite and brucite are visually apparent in plane polarized light as brown veins (Figure 7). All depths contain multiple generations of serpentine with chrysotile overprinted by lizardite that is variably intermixed with brucite. The drill cuttings closer to the surface contain less chrysotile and more lizardite. There is more brucite at depth than closer to the surface, as evidenced by powder XRD and Raman spectroscopy. Brucite is visually associated with brown serpentine as seen in Figure 7.

Both NSHQ14 and NSHQ04 drill cuttings contain widespread magnetite (Figure 8) as identified by Raman microscopy. The magnetite forms both veins and $2-10 \mu \mathrm{m}$ specks, in some cases in 
431 elongate patches or veins cross-cutting all generations of serpentine. Some magnetite is 432 associated in veins with lizardite, but we can use cross-cutting relationships to infer that some of 433 the magnetite postdates formation of all other alteration minerals in these drill cuttings. There is more magnetite observed closer to the surface.

The chemical variation between generations of serpentine in well chip NSHQ04_180m was quantified with electron microprobe (Table 4). Generations 04gen1 and 04-gen2 chrysotile are chemically identical and contain high amounts of trace metals, notably an average of $0.67 \mathrm{wt} \%$ $\mathrm{Al}_{2} \mathrm{O}_{3}, 0.22 \mathrm{wt} \% \mathrm{MnO}$ and 0.33 weight $\% \mathrm{Cr}_{2} \mathrm{O}_{3}$ whereas generation 04-gen3 lizardite has less than $0.07 \mathrm{wt} \%$ of those elements. Generation 04-gen3 lizardite has more $\mathrm{MgO}$ (40.90 wt\% versus $36.06 \mathrm{wt} \%)$ and less $\mathrm{SiO}_{2}(34.60 \mathrm{wt} \%$ versus $36.87 \mathrm{wt} \%)$ than the chrysotile. The totals are low for the serpentine, possibly due to the presence of brucite intermixed with serpentine as well as due to structural water.

444 We tried to quantify the amount of brucite and serpentine in the drill cuttings with TGA analysis (e.g. Lafay et al., 2012). We first measured known amounts of serpentine and brucite separately, and then mixed the two minerals to verify the method (Supplementary Figure 1). The resulting spectra and mass estimates are found in supplemental information. From this test, we see that mixtures of serpentine and brucite are not reliable for determining the mass of both minerals. Thus, we did not utilize TGA as a technique for quantifying the mass of serpentine and brucite.

\subsection{Fe speciation within the drill cuttings}

When comparing bulk Fe-XANES of the drill cuttings to the bulk spectra of a partially serpentinized dunite (OM95-35) from Oman, the drill cutting spectra are more oxidized as noted by the shift in the spectral features to higher energies (Figure 9). Also, the drill cutting spectra are more oxidized than San Carlos olivine, the type specimen characteristic of unaltered olivine. However, it is difficult to discern differences in the Fe-XANES spectra and Fe-speciation (i.e. average oxidation states and mineralogy) between well depths (Figure 9).

The bulk Fe-XANES spectra of the drill cutting samples were fit by Fe XANES model spectra (e.g. Mayhew et al., 2011) of known minerals in the sample: olivine, pyroxene, brucite, magnetite, and serpentine. The linear-combination fits to the data show that serpentine increases in the higher drill cuttings, and olivine and brucite decreases, while pyroxene remains relatively constant (Supplementary Table 3). The changes in bulk Fe speciation are small and due to the number of Fe-bearing phases present, the bulk Fe XANES data is relatively insensitive to noted mineralogical changes such as increased magnetite. We did not collect a highly resolved preedge for the bulk XANES data; thus, it was not possible to quantify a shift in $\mathrm{Fe}(\mathrm{II}) / \mathrm{Fe}(\mathrm{III})$ with depth.

466 We obtained Fe K-edge $\mu$ XANES spectra from the multiple generations of serpentine (as identified from Raman spectroscopy) to determine variations in Fe-oxidation state and coordination within serpentines across samples. Three distinct Fe K-edge serpentine spectra with varying oxidation states are shown in Figure 10. Focusing on the pre-edge $(7108-7118 \mathrm{eV})$ reveals the unoccupied states of the $\mathrm{Fe} 2 \mathrm{p}$ orbital, giving insight into both oxidation state and coordination (Wilke et al., 2001; Andreani et al., 2013a). The serpentine spectra have a shift in the centroid position in the pre-edge to higher energy, which reveals that there is a significant $\mathrm{Fe}(\mathrm{III})$ component. In addition, the increase in the fluorescence intensity at higher energy 
indicates that some of this $\mathrm{Fe}(\mathrm{III})$ is tetrahedrally coordinated. The spectra with the prominent second peak at $7130 \mathrm{eV}$ most closely aligns with the lizardite generation identified by Raman, whereas the most shifted spectrum (prominent peak $\sim 7130$

$.5 \mathrm{eV}$ ) is associated with the chrysotile. The spectrum most shifted to lower energy is San Carlos olivine - a reduced spectrum that contains only $\mathrm{Fe}^{2+}$ (Figure 10). The ferric to ferrous iron ratio could not be quantitatively calculated using the method of Wilke et al. (2001), Muñoz et al. (2013), and Andreani et al. ( 2013a) because these data were collected on a Beamline 2-3 at SSRL using a Si 110 vs. 311 monochromator, resulting in poorer energy resolution shifts and broadens the pre-edge features relative to published standards. However, such quantification will be possible in the future by measuring the same standards across multiple beamlines through inter-laboratory exchange.

\subsection{Magnetic hysteresis analysis of the drill cuttings}

The drill cuttings exhibit two distinctive types of hysteresis behavior. Drill cuttings deeper than $120 \mathrm{~m}$ are paramagnetic while those shallower than $120 \mathrm{~m}$ are ferromagnetic (Table 5). The ferromagnetic samples (NSHQ14_17m, NSHQ14_70m, and NSHQ04_120m) also show superparamagnetic behavior, indicating that a population of the magnetic minerals in the samples are single-domain size particles, likely $<20 \mathrm{~nm}$ (Dunlop, 1973; Butler and Banerjee, 1975; Worm, 1998). We also note a large increase in the saturation magnetization values in the drill cuttings closer to the surface than at depth in both NSHQ04 and NSHQ14 samples (Table 5).

The measured changes in magnetic character augment the petrological observation of increased magnetite closer to the surface. It is possible to calculate an approximate mass of magnetite in the sample if we used a proportionality constant of $92 \mathrm{~A} \cdot \mathrm{m}^{2} / \mathrm{kg}$ to empirically correlate the saturation magnetization to the amount of magnetite, as conducted by Malvoisin et al. (2012). However, such a quantification of magnetite would assume that the sole magnetic carrier in the sample is magnetite. This assumption may be false in our samples due to the prevalence of FeII/III-bearing serpentine grains also mixed within the matrix. In addition, the magnetite grains are present across a large size distribution - both nanoscale and microscale - which affects the hysteresis parameters that should be applied. For example, we note that the upper drill cuttings exhibit superparamagnetic behavior, yet the saturation magnetization values used to calculate the amount of magnetite will only take into account the larger, microscale magnetite grains that contribute to the non-superparamagnetic components of the data. Thus such a calculation would be an underestimate of the amount of magnetite present in the drill cuttings; instead, we simply utilize the suite of magnetic data to show several lines of evidence indicating increased magnetite formation at shallow depths.

\subsection{S rRNA analysis of DNA collected from well fluids}

We sequenced the hypervariable V4-V5 region of the 16S rRNA gene from DNA extracted from filters that were loaded with biomass by pumping fluids from each well. Analysis of the 16S rRNA data shows that the NSHQ14 16S sequences were $99.5 \%$ bacteria and $0.05 \%$ archaea. Similar dominance of bacterial sequences was observed in NSHQ04 (99.4\% bacteria and 0.06\% 
515 archaea). The Bacteria are dominated by members of the Deinococcus-Thermus, Nitrospirae, 516 Firmicutes, Chloroflexi, and Proteobacteria phyla. Fluids from both wells contain candidate 517 phylum OP1 (1.1 and 2.8\%, respectively), and NSHQ04 additionally has candidate phylum OD1. 518 The species richness, as determined by the number of OTUs from each well, is 1737 for 519 NSHQ04 fluids vs. 710 for NSHQ14. NSHQ04 is more diverse than NSHQ14.

520 We found that Meiothermus (phylum Deinococcus-Thermus, class Deinococci) comprises 8.6\% 521 (NSHQ04) and 46.1\% (NSQH14) of the operational taxonomic units (OTUs) in both wells. 522 Thermodesulfovibrionaceaea (phylum Nitrospirae), a sulfate-reducer, comprises $21.6 \%$ of 523 NSHQ14 and 1.4\% of NSHQ04. Chloroflexi is prominent in NSHQ04, 5.3\%, but only $0.1 \%$ in 524 NSHQ14 (Table 6). Both wells contain Firmicutes (class Clostridia family Anaerobrancaceae), 525 fermentative microorganisms, and Proteobacteria (genus Hydrogenophaga), hydrogen-oxidizing 526 bacteria found in other serpentinizing systems (Brazelton et al., 2013; Suzuki et al., 2013). The 527 fluids from both wells notably contain methanogen Methanobacterium, which can utilize 528 hydrogen and variable carbon sources such as formate to produce methane. Methylococcus, a 529 methanotroph, is also present. 


\section{Discussion}

531 This study explores the mineralogy and aqueous geochemistry of modern water/rock reactions associated with low temperature serpentinization and hydrogen production in Oman and how these processes may give rise to habitable conditions for microbial life in the peridotite aquifer. We then use 16S rRNA sequencing of DNA extracted from subsurface fluids to investigate the phylogenetic diversity of the fluid microbial communities and infer potential microbial metabolisms sustained in-situ.

\subsection{Fluid chemistry of low temperature serpentinization}

Modern alteration of primary minerals in the aquifer is evident from the abundant $\mathrm{Ca}^{2+}$ and $\mathrm{OH}^{-}$ in peridotite hosted well waters NSHQ04 and NSHQ14 (Neal and Stanger, 1983; Neal and Stanger, 1984; Neal and Stanger, 1985). Neal and Stanger $(1983,1984,1985)$ extensively studied the hydrogeology of Oman's fluids and coined these hyperalkaline waters $(\mathrm{pH}>11)$ containing $\mathrm{Ca}^{2+}-2 \mathrm{OH}^{-}$as Type II fluids, following the initial observation of Barnes and O'Neil (1969). They are situated in serpentinized dunite and harzburgite and are derived from serpentinization reactions with subsurface fluids that are isolated from the atmosphere. The hydration of olivine and pyroxene causes the water to become enriched in $\mathrm{Ca}^{2+}-\mathrm{OH}^{-}$(Barnes and O'Neil, 1969; Neal and Stanger, 1984; Bruni et al., 2002; Kelemen et al., 2011):

$$
4 \mathrm{Mg}_{2} \mathrm{SiO}_{4}+\mathrm{CaMgSi}_{2} \mathrm{O}_{6}+7 \mathrm{H}_{2} \mathrm{O}=3 \mathrm{Mg}_{3} \mathrm{Si}_{2} \mathrm{O}_{5}(\mathrm{OH})_{4}+\mathrm{Ca}^{2+}+2 \mathrm{OH}^{-}
$$

The $\mathrm{Ca}^{2+}$ is released from diopside (present in all drill cuttings), and then accumulates in the water because $\mathrm{Ca}^{2+}$ is not incorporated into serpentine minerals (Barnes et al., 1967). These Type II fluids are carbon-depleted and when they emerge at surface springs, they rapidly mix with atmospheric carbon dioxide to precipitate carbonate minerals (Stanger, 1986; Kelemen and Matter, 2008; Kelemen et al., 2011; Paukert et al., 2012; Mervine et al., 2014). The $\mathrm{Ca}^{2+}$ values we measure in the deeper subsurface fluids are $\sim 1 \mathrm{mM}$ higher than those reported from hyperalkaline springs, presumably because $\mathrm{Ca}^{2+}$ in the subsurface has not been depleted through the precipitation of carbonate minerals. Thus, sampling the Type II fluids in wells before they interact with atmospheric $\mathrm{CO}_{2}$ in the unsaturated zone or on the surface provides a more direct assessment of the water composition in the aquifer.

The subsurface well water contains more $\mathrm{Cl}^{-}$than found in Oman rainwater and hyperalkaline surface seeps (Paukert et al., 2012) which provides additional proof that modern water/rock interaction is occurring. We infer that the high $\mathrm{Cl}^{-}$concentrations are due to the presence of $\mathrm{Cl}^{-}$ that was incorporated in the Oman peridotite during initial, high-temperature serpentinization near an oceanic spreading ridge, and dissolved in groundwater during ongoing weathering (Stanger, 1986). The $\mathrm{Cl}^{-}$is presumably at lower concentrations at the surface seeps than in the wells because it is precipitating with carbonates in salt.

The wells only contain Type II fluids; however, the shallow peridotite aquifer in Oman also hosts $\mathrm{Mg}^{2+}-2 \mathrm{HCO}_{3}{ }^{-}$as observed by Barnes and O'Neil (1969). These are termed Type I fluids (Neal and Stanger, 1983; Kelemen et al., 2011) and are moderately alkaline fluids of a $\mathrm{Mg}^{2+}-2 \mathrm{HCO}_{3}{ }^{-}$ composition found in the shallow groundwater ( $\sim \mathrm{pH} 8-9)$. In Oman, Type I fluids are typically found in wadi (channel that is dry except during rainy seasons) pools, ultramafic wadi gravels, 
and water wells (e.g., Neal and Stanger, 1985; Paukert et al., 2012) and form through the following simplified reaction (e.g. Kelemen et al., 2011):

$$
\mathrm{Mg}_{2} \mathrm{SiO}_{4}+4 \mathrm{CO}_{2}+2 \mathrm{H}_{2} \mathrm{O}=2 \mathrm{Mg}^{2+}+4 \mathrm{HCO}_{3}^{-}+\mathrm{SiO}_{2}
$$

Atmospheric carbon dioxide dissolves in the water and forms bicarbonate as olivine and serpentine minerals in the near-surface react with the waters and release magnesium ions and silica. Although we did not observe Type I fluids in this study, their mixing and interaction with Type II fluids may be influencing water/rock reactions and microbial diversity in the subsurface. In particular, the presence of oxygenated Type I fluids in the highly fractured upper portion of the aquifer may explain the aerobic organisms detected by 16S rRNA sequencing.

\subsection{Mineral assemblages associated with low temperature hydrogen production}

We investigated the mineralogy of the subsurface aquifer to see if the mineral assemblages give insight into the water/rock reactions and mechanisms that produce hydrogen at low-temperature. The drill cuttings contain serpentine, brucite, and magnetite, as is common in partially serpentinized peridotites. Although the drill cuttings are heavily serpentinized, they still contain relict olivine at depth that diminishes towards the surface, which suggests olivine may be the dominant mineral reacting with the in-situ fluids. There is a significant portion of unaltered pyroxene that could also be reacting; however, few zones of pyroxene alteration have been observed. Pyroxene alteration can be a dominant reaction in other serpentinizing sites (Klein et al., 2009; Marcaillou et al., 2011; Andreani et al., 2013a). A common alteration product of pyroxene is talc $\left[\mathrm{Mg}_{3} \mathrm{Si}_{4} \mathrm{O}_{10}(\mathrm{OH})_{2}\right]$ under conditions of high silica activity (Frost and Beard, 2007; McCollom and Bach, 2009; Klein et al., 2013). We do not observe any talc formation; thus, we do not believe pyroxene alteration is dominating the water/rock reactions, although the high concentrations of $\mathrm{Ca}^{2+}$ in the fluids do suggest that at least some pyroxene dissolution is occurring in the hyperalkaline aquifer.

The multiple generations of serpentine observed in the drill cuttings reveal that the mantle peridotite experienced multiple periods of water/rock alteration. The mantle section of the ophiolite was first serpentinized near an oceanic spreading ridge, during emplacement of the ophiolite onto the Arabian continental margin, and/or during subaerial erosion and a subsequent marine transgression in the late Cretaceous (Kelemen and Matter, 2008; Hanghøj et al., 2010; Mervine et al., 2014). These events may have caused formation of the extensive chrysotile matrix seen in the drill cuttings. The chrysotile is overprinted by lizardite veins; however, we cannot infer a formation temperature due to the fact that chrysotile is metastable relative to lizardite (Evans, 2004).

We characterized the Fe content and speciation of the serpentine to investigate reservoirs of Fe in the system. Both the lizardite and chrysotile contain $\sim 7-8 \mathrm{wt} . \% \mathrm{FeO}_{\mathrm{T}}$ (considering all $\mathrm{Fe}$ as $\mathrm{Fe}^{2+}$ ). In average natural samples, chrysotile contains $3 \mathrm{wt} . \% \mathrm{FeO}_{\mathrm{T}}$, while lizardite ranges from 2-8 mol.\% Fe (Evans et al., 2009; Streit et al., 2012). Thus, the chrysotile in Oman is Fe-rich while the lizardite is average. Characterization of serpentine in our samples with electron microprobe and XANES confirms the presence both Fe(II) and Fe(III) in the serpentine. Fe(III) can substitute into both the octahedral and tetrahedral sites, replacing $\mathrm{Si}^{4+}$, to form cronstedtite, $\left(\mathrm{Mg}_{2}, \mathrm{Fe}^{3+}\right)_{3}\left(\mathrm{Fe}^{3+}, \mathrm{Si}\right)_{2} \mathrm{O}_{5}(\mathrm{OH})_{4}$ (Frost and Beard, 2007; Klein et al., 2009; Evans, 2010; Streit et al., 2012). The formula for chrysotile inferred during early alteration of the peridotite is 
$617\left(\mathrm{Mg}_{2.79} \mathrm{Fe}^{\mathrm{II}}{ }_{0.10} \mathrm{Fe}^{\mathrm{III}}{ }_{0.11}\right)\left(\mathrm{Si}_{1.89} \mathrm{Fe}^{\mathrm{III}}{ }_{0.11}\right) \mathrm{O}_{5}(\mathrm{OH})_{4}$ while the younger lizardite formula is difficult to 618 determine because it is intermixed with brucite. It contains less $\mathrm{Si}$ (perhaps due to intergrown 619 brucite) than the chrysotile, but has high Fe concentrations $\left(6-8 \mathrm{wt} \% \mathrm{FeO}_{\mathrm{T}}\right)$, with Fe occupying both tetrahedral and octahedral sites.

$\mathrm{Fe}(\mathrm{III})$ rich serpentine forms at low temperatures $\left(<200^{\circ} \mathrm{C}\right)$ (Streit et al., 2012; Klein et al., 2013) and may have played an important role in hydrogen generation in Oman because it is another reservoir of oxidized $\mathrm{Fe}$ (besides magnetite), that can form during $\mathrm{Fe}$ (II)-driven reduction of water to form hydrogen. Generally, the oxidized Fe(III) is assumed to partition into magnetite (equation 1). However, at lower temperatures, there is a decreasing thermodynamic drive for magnetite formation (Klein et al., 2013), and indeed magnetite may redissolve into serpentine at low temperature (Streit et al. 2012). Thus, Fe(III)-rich serpentine becomes an important mineral to consider as an indicator of hydrogen production during serpentinization (Klein et al., 2009; Marcaillou et al., 2011; Andreani et al., 2013b). The average oxidation state of Fe in the drill cuttings is greater than that of partially serpentinized dunite from Oman and San Carlos olivine (Figure 9). This reveals rocks interacting with hyperalkaline fluids have been altered after their initial formation when they contained mostly Fe(II). Moreover, spatially-resolved Fe K-edge XANES data on drill cuttings reveal the presence of Fe(III)-rich serpentine. Our observation of $\mathrm{Fe}(\mathrm{III})$ rich serpentine is consistent with observations from Streit et al. (2012) of Fe(III)-rich serpentine in Oman rocks undergoing low-temperature alteration processes, and from Andreani et al. (2013) during serpentinization at mid-ocean ridges $\left(<150-200^{\circ} \mathrm{C}\right)$.

We find that in addition to Fe(III)-rich serpentine, magnetite is also formed during lowtemperature serpentinization in Oman in the upper portions of the two wells studied. The simplified unbalanced equation (6) presented in Klein et al. (2013b) shows how magnetite and $\mathrm{Fe}(\mathrm{III})$-rich serpentine can accommodate hydrogen production:

$$
\begin{gathered}
(\mathrm{MgFe})_{2} \mathrm{SiO}_{4}+v \mathrm{H}_{2} \mathrm{O}=w\left(\mathrm{MgFe}^{\mathrm{II}}\right) \mathrm{OH}_{2}+x\left(\mathrm{MgFe}^{\mathrm{II} / \mathrm{III}}\right)_{3}\left(\mathrm{SiFe}^{\mathrm{III}}\right)_{2} \mathrm{O}_{5}(\mathrm{OH})_{4} \\
+y \mathrm{Fe}_{3} \mathrm{O}_{4}+z \mathrm{H}_{2}
\end{gathered}
$$

Such reactions may contribute to the high levels of $\mathrm{H}_{2}$ found in the subsurface fluids. As noted above, and demonstrated in Figure 8, there is extensive magnetite in our samples, with some of it forming veins that cross-cut all of the serpentine assemblages.

Downhole bulk sample magnetic hysteresis analyses indicate that the drill cuttings above 70 and 120 meters in NSHQ14 and NSHQ04 wells (respectively) are ferromagnetic (i.e. minerals that retain remnant magnetization) and have superparamagnetic grain sizes, further confirming that there is increased magnetite in drill cuttings closer to the surface. The drill cuttings at depth, on the other hand, have a paramagnetic signature (i.e. no retainable magnetic properties without applied field). The nanometer size calculation of the magnetite particles based on hysteresis behavior (Tauxe et al., 2014) shows there are multiple populations of magnetite in these rocks 
Brucite can accommodate $\mathrm{Fe}$ (II) in its structure that can then be oxidized during subsequent alteration to produce hydrogen at low temperatures (Klein et al., 2013). Typically, brucite forms mesh rims around olivine and traps $\mathrm{Fe}(\mathrm{II})$ in a stable mineral structure and prevents hydrogen generation (Klein et al., 2009; Evans, 2010). However, in our drill cutting samples, and in our comparison Oman dunite sample, we observe brucite intimately intermixed with lizardite. It is not possible to determine an iron content for the brucite due to the fact that it is not present in large enough, serpentine-free areas for analysis. Electron microprobe measurements were not used to constrain Fe-contents of brucite intermixed with serpentine because Fe can substitute into $\mathrm{Si}$ sites in serpentine (particularly in Fe(III) rich serpentine) as well as Mg sites in brucite, thus an estimate of brucite calculated from electron microprobe would be inaccurate. However, Raman analysis shows a distinct change in the brucite spectrum from that of the pure $\operatorname{Mg}(\mathrm{OH})_{2}$ endmember. Additionally, brucite in serpentinizing systems commonly contains iron; brucite can include greater than $10 \mathrm{wt} \% \mathrm{FeO}_{\mathrm{T}}$, with increasing $\mathrm{Fe}$ content at lower temperatures in the same bulk composition (Moody, 1976; Klein et al., 2009). Yet brucite is not thermodynamically stable at the silica activities measured in our fluid samples (Table 1). Thus, we propose that brucite should react with silica-rich fluids in the aquifer (Bach et al., 2006), driving Fe(II) to undergo oxidation to form $\mathrm{Fe}(\mathrm{III})$-rich serpentine and/or magnetite while concurrently reducing $\mathrm{H}_{2} \mathrm{O}$ to make $\mathrm{H}_{2}$ (see equation 7 below).

There are several possible reasons for the high silica activity in our fluid samples. First, the fluids in the wells are high in $\mathrm{Ca}^{2+}$. Well NSHQ04 is close to the Moho, the zone of contact between peridotite and gabbro. Thus, it is possible gabbro-equilibrated fluids are interacting with the peridotite aquifer. Fluid that has equilibrated with gabbro has higher silica activity, and it will destabilize and consume brucite (Frost and Beard, 2007). However, there is insufficient hydrological information about the region surrounding the wells to test this hypothesis, and the similarity of fluids in wells NSHQ04 (near the Moho) and NSHQ14 (kilometers from the Moho) seems inconsistent with this hypothesis.

Bach et al. (2006) suggest that high Si fluids are generated when olivine nears exhaustion in the host rock and pyroxene alteration becomes a more important control on fluid chemistry. This is plausible given the low amount of relict olivine remaining in the drill cuttings.

A third possibility, as shown in equation 3, is that the generation of Type I waters in the shorter residence fluid-flow pathways can lead to fluids with high silica activities. Subsequently, we may be observing the destabilization of brucite in the host rock when Type I waters mix with Type II fluids within the shallow subsurface. This is supported by the observation of decreasing brucite in the highly serpentinized samples near the surface where Type I waters may be present.

There is increased extent of serpentinization in the drill cuttings near the surface as opposed to at depth, which suggests varying hydrological pathways in the subsurface. The top tens of meters below the surface could be subject to more variable conditions with higher water/rock ratios and/or interaction with Type I fluids than rock at depth due to rainwater recharge. This can lead to increased fracture permeability (e.g., Kelemen and Hirth, 2012) and periodic exposure to oxygen, as well as shorter fluid residence times. Thus, the fluids will not be equilibrated with the mineral assemblages, leading to more rapid destabilization and alteration, as well as increased oxidation and drive to form magnetite. 


\subsection{Hydrogen generating reactions}

Based on our observations, we infer that three different hydrogen generating reactions have occurred in the subsurface. An initial serpentinization stage prior to modern water/rock reactions produced hydrogen from alteration of olivine and led to the production of Fe(II)-bearing brucite and $\mathrm{Fe}(\mathrm{III})$ rich serpentine (chrysotile generation):

$(\mathrm{MgFe})_{2} \mathrm{SiO}_{4}+\mathrm{H}_{2} \mathrm{O}=x\left(\mathrm{MgFe}^{\mathrm{II}}\right)(\mathrm{OH})_{2}+y\left(\mathrm{MgFe}^{\mathrm{II} / \mathrm{III}}\right)_{3}\left(\mathrm{SiFe}^{\mathrm{III}}\right)_{2} \mathrm{O}_{5}(\mathrm{OH})_{4}+z \mathrm{H}_{2}$

There is relict olivine in the deep drill cuttings that is replaced by serpentine at shallower depths, so similar $\mathrm{H}_{2}$ generating reactions could occur today. Moreover, less brucite might form because modern silica activities in the fluids are too high for brucite stability. Thus we suggest that relict olivine is now reacting to form new Fe(III)-bearing lizardite and hydrogen at low temperatures:

$$
(\mathrm{MgFe})_{2} \mathrm{SiO}_{4}+\mathrm{H}_{2} \mathrm{O}=x\left(\mathrm{MgFe}^{\mathrm{II} / \mathrm{III}}\right)_{3}\left(\mathrm{SiFe}^{\mathrm{III}}\right)_{2} \mathrm{O}_{5}(\mathrm{OH})_{4}+y \mathrm{H}_{2}
$$

Currently, a high silica fluid is interacting with the rock, destabilizing the Fe(II)-bearing brucite (as modeled in Geochemist Workbench). This leads to the formation of magnetite and lizardite, with the production of hydrogen:

$$
\left(\mathrm{MgFe}^{\mathrm{II}}\right)(\mathrm{OH})_{2}+\mathrm{SiO}_{2}=x\left(\mathrm{Fe}^{\mathrm{II}} \mathrm{Fe}^{\mathrm{III}}{ }_{2}\right) \mathrm{O}_{4}+y\left(\mathrm{MgFe}^{\mathrm{II} / \mathrm{III}}\right)_{3}\left(\mathrm{SiFe}^{\mathrm{III}}\right)_{2} \mathrm{O}_{5}(\mathrm{OH})_{4}+z \mathrm{H}_{2}
$$

728

729

730

731

732

733

734

735

736

737

738

739

740

741

742

743

744

745

746

747

748

749

750

The destabilization of Fe(II)-bearing brucite to form magnetite and serpentine, and the alteration of olivine to Fe(III) rich serpentine, should both produce hydrogen at low temperatures. This model of alteration and hydrogen generation is consistent with observations by Andreani et al. (2013b) that serpentinites from mid-ocean ridges contain both $\mathrm{Fe}(\mathrm{III})$-serpentine and more magnetite as the degree of serpentinization increases.

\subsection{Isotopic signature of hydrogen and methane}

The isotopic signature of the $\mathrm{H}_{2}$ serves as a valuable indicator of formation temperature, which complements mineralogical observations of serpentinization leading to hydrogen production. (Neal and Stanger, 1983) collected gas samples from surface hyperalkaline seeps and observed low $\delta \mathrm{D} \mathrm{H}_{2}$ values (-697\%o and -714\%o) similar to those measured from our well samples (-680\%o and $-686 \%$ ). They noted that $\mathrm{H}_{2-}$ and $\mathrm{CH}_{4}$-rich gases $\left(\mathrm{H}_{2}\right.$ as high as $99 \%$ and $\mathrm{CH}_{4}$ as high as $4.3 \%$ ) emerge at hyperalkaline surface seeps, whereas the well fluids provide access to dissolved gases in the host rock itself. Sherwood Lollar et al. (1993), Proskurowski et al. (2006), and Abrajano et al. (1990) also found negative $\delta \mathrm{D}$ gases that formed at low temperatures $\left(<200^{\circ} \mathrm{C}\right)$ at other serpentinizing sites (both continental and oceanic), as shown in Table 4.

The dissolved gases from Oman subsurface wells uniformly contain some of the most negative $\delta \mathrm{D}$ hydrogen gas found in nature. We calculate a formation temperature of $\sim 50^{\circ} \mathrm{C}$ by applying the geothermometer of Bottinga (1969) to the coupled $\delta \mathrm{D} \mathrm{H}_{2}$ and $\delta \mathrm{D} \mathrm{H}_{2} \mathrm{O}$ in the well fluids. Assuming the geothermal gradient at NSHQ14 is approximately $25^{\circ} \mathrm{C} / \mathrm{km}$ (Paukert et al., 2012), the gases are hypothesized to form at a depth of less than $2 \mathrm{~km}$. A formation temperature of 
$\sim 50^{\circ} \mathrm{C}$ supports the hypothesis that low-temperature serpentinization and hydrogen formation is occurring in the Oman aquifer, rather than $\mathrm{H}_{2}$ being physically released from hydrogen inclusions that formed during higher temperature serpentinization events (McCollom and Seewald, 2001). We verified the lack of gas-rich inclusions in relict olivine by extensively probing the olivine grains by confocal Raman spectroscopy. However, the mantle section of the ophiolite is up to $8 \mathrm{~km}$ thick (Ravaut et al., 1997); thus, the $\mathrm{H}_{2}$ could be generated at temperatures as high as $200^{\circ} \mathrm{C}$ and then migrate upwards to the surface. In this case, the current negative $\delta \mathrm{D}$ of the $\mathrm{H}_{2}$ could instead represent isotopic exchange and re-equilibration between the $\mathrm{H}_{2}$ and $\mathrm{H}_{2} \mathrm{O}$ after formation of the $\mathrm{H}_{2}$ as the waters circulate to shallower, cooler depths.

NSHQ04 fluids contain millimolar amounts of $\mathrm{CH}_{4}$, which may be produced abiotically due to the highly reducing conditions reflected in the abundant $\mathrm{H}_{2}$ in the system. In olivine dissolution reactions at $30{ }^{\circ} \mathrm{C}$, (Neubeck et al., 2011) observed measureable $\mathrm{CH}_{4}$, potentially through the oxidation of $\mathrm{H}_{2}$ and reduction of $\mathrm{CO}_{2}$ (Sleep et al., 2004). However, the $\mathrm{CH}_{4}$ detected by Neubeck et al. (2011) could have been released from fluid inclusions, or produced by reaction of fluid with the experimental reaction vessel. At higher temperature $\left(>120^{\circ} \mathrm{C}\right), \mathrm{CH}_{4}$ production can occur abiotically through Fischer-Tropsch-type or Sabatier reactions, through catalysis by magnetite and awaruite (Ni-Fe alloy) commonly found in serpentinites (Frost, 1985; Lorand, 1987; Horita and Berndt, 1999). Etiope et al. (2013) suggested catalysts such as ruthenium or chromite produce methane at temperatures $<50^{\circ} \mathrm{C}$. Such low temperature methane production may be possible in Oman due to the abundance of magnetite, chromite and awaruite found in the partially serpentinized mantle peridotites. Alternatively, methane formation could be biologically mediated by methanogens.

The $\delta^{13} \mathrm{C} \mathrm{CH}_{4}$ signatures are the highest values reported in the literature thus far despite the wide range of methane isotopic compositions compiled in the past $30+$ years. Plots comparing the ranges of $\delta^{13} \mathrm{C} \mathrm{CH}_{4}$ and $\delta \mathrm{D} \mathrm{CH}$ found in various geologic environments (Whiticar, 1990; Etiope et al., 2013) give context to methane isotopic compositions measured in the peridotite-hosted wells in Oman. Thermogenic natural gas has been extensively studied, as have gases from extreme environments like hyperalkaline lakes and Antarctic ice sheets (Whiticar, 1990). The previously highest documented $\delta^{13} \mathrm{C} \mathrm{CH}_{4}$ values (-1.6\%) were found from the Ilimaussaq inclusions Greenland (Laier and Nytoft, 2012; Etiope et al., 2013). That methane was hypothesized to have a biological origin, and subsequent sediment burial and partial loss by diffusion during uplift and erosion enriched the gas in isotopically heavy methane (Laier and Nytoft, 2012). A similar explanation is plausible for the enriched $\delta^{13} \mathrm{C} \mathrm{CH}_{4}$ values in Oman. Alternatively, if the methane we observe in Oman formed abiotically at $50^{\circ} \mathrm{C}$ at a depth of $\sim 2 \mathrm{~km}$, similar to the $\mathrm{H}_{2}$, slow diffusion upwards from depth could fractionate and enrich the remaining methane in isotopically heavy carbon after the lighter ${ }^{12} \mathrm{C} \mathrm{CH}_{4}$ has diffused away. However, this should have a similar effect on the hydrogen isotopic composition of the methane as well, which we did not observe. The methane-hydrogen $\mathrm{D} / \mathrm{H}$ fractionation can be used to estimate temperature of formation of methane (Horibe and Craig, 1995) at $\sim 70^{\circ}+/-3^{\circ} \mathrm{C}$.

The isotopic composition of methane collected from wells in Oman falls near the traditionally defined abiotic range. Abiotic methane tends to have $\delta^{13} \mathrm{C} \mathrm{CH}_{4}$ values greater than $-50 \%$ and $\delta \mathrm{D}$ of $\mathrm{CH}_{4}$ can range from -450 to $-50 \%$ (Etiope and Sherwood Lollar, 2013; Etiope et al., 2013). Bacterial reduction of $\mathrm{CO}_{2}$ to methane gives negative $\delta^{13} \mathrm{C} \mathrm{CH}_{4}$ values as low as $-110 \%$ and $\delta \mathrm{D}$ 
$\mathrm{CH}_{4}$ down to $-531 \%$ (Whiticar, 1999); thus, methane from Oman does not have a traditional bacterial signature. Low temperature $\mathrm{CH}_{4}$ production has been experimentally demonstrated with ruthenium and rhodium catalysts (Jacquemin et al., 2010). Platinum group metal inclusions, including $\mathrm{Ru}$ and $\mathrm{Rh}$, are found in chromites (e.g, Jacquemin et al., 2010). Platinum group metals in chromites in Oman could be catalyzing low temperature methane formation and leading to a heavy $\delta^{13} \mathrm{C} \mathrm{CH}_{4}$ signature, but there are no experimental data to confirm this hypothesis. $\delta^{13} \mathrm{C}$ enriched $\mathrm{CH}_{4}$ can also be produced by extensive biological oxidation of biogenic or abiogenic methane that enriches the residual methane in ${ }^{13} \mathrm{C}$ (Whiticar and Faber, 1986; Whiticar, 1999). Thus, if methane cycling is active in the subsurface aquifer, the isotopic signature of $\mathrm{CH}_{4}$ may not be an unequivocal marker of the methane formation pathway (Whiticar and Faber, 1986; Templeton et al., 2006).

The processes giving rise to the heavy $\delta^{13} \mathrm{C} \mathrm{CH}_{4}$ in Oman cannot be elucidated without further investigation of the microbial and low-temperature abiotic pathways that are giving rise to the production of $\mathrm{mM}$ concentrations of $\mathrm{CH}_{4}$. First, the source of carbon must be assessed. The $\delta^{13} \mathrm{C}$ signature of carbonates mineralized in Oman peridotites provide some insights into the isotopic signature of the carbon pool. The carbonate found in the drill cuttings $\delta^{13} \mathrm{C}$ ranges from -1.48 to $7.05 \%$ while the $\delta^{18} \mathrm{O}$ is -7.73 to $-11.49 \%$. These values are similar to the $\mathrm{Mg}$-rich carbonate veins from outcrops and roadcuts that have $\delta^{13} \mathrm{C}$ ranging from -25.98 to $0.98 \%$ and $\delta^{18} \mathrm{O}$ from 7.04 to 5.56\% (Clark and Fontes, 1990; Kelemen and Matter, 2008; Kelemen et al., 2011; Mervine et al., 2014). The negative $\delta^{13} \mathrm{C}$ values as low as $-26 \%$ probably formed through a mechanism dominated by kinetic isotope fractionation during carbonate precipitation. Both the values from the drill cuttings and outcrops are still lighter than $\delta^{13} \mathrm{C}$ in the $\mathrm{CH}_{4}$, suggesting that even if the entire DIC pool was converted to methane under extreme carbon limitation, processes such as further $\delta^{13} \mathrm{C}$ enrichment by diffusion or partial oxidation of the methane must be invoked.

\subsection{Potential metabolic pathways supported by hyperalkaline fluids}

The hyperalkaline fluids in Oman contain electron donors and acceptors to sustain anaerobic microbial metabolisms. There are millimolar amounts of $\mathrm{H}_{2}$ and $\mathrm{CH}_{4}$ to serve as electron donors, but dissolved organic acids were not detected at the micromolar detection limit. NSHQ04 notably contains high levels of $\mathrm{SO}_{4}{ }^{2-}$, which may be a source of critical electron acceptors for microorganisms (ex. sulfate reducers). Nitrate found in both wells is another potential electron acceptor that can be coupled with oxidation of $\mathrm{H}_{2}, \mathrm{CH}_{4}$ and $\mathrm{Fe}(\mathrm{II})$.

The aqueous geochemistry of the well fluids can support several potential metabolic pathways. Well fluids contain more sulfate and nitrate than samples from hyperalkaline seeps with comparable $\mathrm{pH}$, and elevated $\mathrm{H}_{2}$ and $\mathrm{CH}_{4}$ (Paukert et al., 2012). Thus, nitrate and sulfate reduction at depth, tied to hydrogen oxidation, is likely. The high methane concentrations in NSHQ04 can support anaerobic oxidation of methane (AOM) (Hoehler et al., 1994; Joye et al., 2004), especially considering AOM consortia are often syntropically associated with sulfatereducing microorganisms. The following reactions are often invoked for serpentinizing systems and may be relevant metabolisms for microbial life in the subsurface of Oman:

a. $\mathrm{CO}_{2(\mathrm{aq})}+4 \mathrm{H}_{2(\mathrm{aq})}=\mathrm{CH}_{4(\mathrm{aq})}+2 \mathrm{H}_{2} \mathrm{O}_{(\mathrm{l})}$

b. $2 \mathrm{NO}_{3}{ }^{-}+10 \mathrm{Fe}^{2+}+24 \mathrm{H}_{2} \mathrm{O}_{(\mathrm{l})}=10 \mathrm{Fe}(\mathrm{OH})_{3}+\mathrm{N}_{2}+18 \mathrm{H}^{+}$ 
c. $\mathrm{NO}_{3}{ }^{-}+2.5 \mathrm{H}_{2(\mathrm{aq})}+\mathrm{H}^{+}=0.5 \mathrm{~N}_{2(\mathrm{aq})}+3 \mathrm{H}_{2} \mathrm{O}_{(\mathrm{l})}$

(Hoehler et al., 1994; Nielsen and Nielsen, 1998; Chapelle et al., 2002; Cardace and Hoehler, 2009; Haroon et al., 2013; Cardace et al., 2015). These metabolic strategies provide the energy to generate an electrochemical gradient to produce ATP. However, it is energetically taxing to generate a traditional hydrogen pump at high pH (Hicks et al., 2010; Suzuki et al., 2014). Microorganisms in Oman may be employing a sodium or calcium motive force to generate ATP instead of a proton pump. Many microorganisms pump $\mathrm{H}^{+}$ions outside the cell to create an energy gradient, but in a high $\mathrm{pH}$ environment, this $\mathrm{H}^{+}$quickly combines with abundant $\mathrm{OH}^{-}$in the environment and cannot be utilized by the cell. Microorganisms can adapt to hyperalkaline conditions by generating a sodium motive force instead of pumping protons onto the surface of a cell inundated with $\mathrm{OH}^{-}$. There is ample $\mathrm{Na}^{+}$in the fluids, so organisms in Oman may use a sodium motive force to cope with high $\mathrm{pH}$ environments. Alternatively, recent work has shown that some organisms can utilize a proton motive force, even under alkaline conditions (Mulkidjanian et al., 2008; Hicks et al., 2010; Suzuki et al., 2014). The pH in NSHQ04 is slightly lower than in NSHQ14, potentially making it more habitable for microorganisms. NSHQ04 also has more abundant electron donors, nitrate and sulfate, than NSHQ14, further increasing its habitability.

\subsection{Organisms detected in fluids from $16 S$ rRNA sequencing}

Predictions about potential metabolic pathways in serpentinizing systems aid in interpreting $16 \mathrm{~S}$ rRNA data from the fluids and allow us to place the phylogeny of the organisms detected in the subsurface fluids within a context of potential functional activities. There is a curious mixture of both aerobic and strictly anaerobic microorganisms in the subsurface. DNA extracted from well fluids shows the presence of aerobic organisms Meiothermus and Hydrogenophaga that require oxygen as an electron acceptor. Meiothermus is considered to be obligately aerobic and chemoorganotrophic, capable of utilizing a range of carbon sources from glucose to acetate (Tindall et al., 2010). Hydrogenophaga is chemoorganotrophic or chemolithoautotrophic, and it oxidizes hydrogen and reduces organic material or heterotrophically denitrifies nitrate (Willems et al., 1989). We also found members of the Clostridia class and Methanobacterium genera, which are strict anaerobic fermenters and methanogens, respectively. Anaerobes Thermodesulfovibrionaceaea are also present, which are sulfate reducing bacteria that use hydrogen as electron donors and ferment pyruvate or other organics (Haouari et al., 2008). We likely significantly mixed the deep and shallow well fluids during pumping, so there may be internal variation in the fluid $\mathrm{Eh}$ as a function of depth, and intervals of variable permeability, that affect microbial community composition and function in ways that we cannot yet identify. The near-surface fluids probably have a shorter residence time and more recent interaction with ambient atmospheric oxygen. The mixture of organisms may point to an upper zone of more oxidized fluids in the wells (e.g. Type I fluids), leading to an interesting geochemical interfaces that microorganisms can exploit.

Methanobacterium, a methanogen, is present in NSHQ04 and NSHQ14. This may explain the 
$\mathrm{CO}_{2}$ to produce methane (Balch et al., 1979). Similar Methanobacterium sequences have also been observed in the Zambales ophiolite seeps (Woycheese et al., 2015). Methanogenesis is oftentimes invoked as a metabolic pathway in serpentinizing environments due to the abundant hydrogen and methane in the fluids (Chapelle et al., 2002; Cardace and Hoehler, 2009; Cardace et al., 2015). In order to determine Methanobacterium's contribution to the $\mathrm{CH}_{4}$ in the wells, it will be necessary to investigate the abundance and activity of the methanogens along with the isotopic signature of the $\mathrm{CH}_{4}$ that they produce.

893 Candidate phylum OP1 was first detected in hot springs, but curiously it is present in the mesophilic, hyperalkaline conditions of the Oman subsurface. OP1 was first found in a neutral hot spring $\left(75-95^{\circ} \mathrm{C}\right)$ in Yellowstone rich in iron, sulfide, carbon dioxide, and hydrogen (Kumar and Saravanan, 2011). There is a nearly complete genome for the OP1 Candidatus 'Acetothermus autotrophicum' that suggests it is one of the earliest bacteria to branch from the last universal common ancestor (Takami et al., 2012). 13 of the OTUs from NSHQ14 have 100\% identity to this genome, whereas the other 250 OTUs are other species from candidate phylum OP1. The genome for Candidatus 'Acetothermus autotrophicum' has a high GC content (61.9\%), and this organism is estimated to have an ideal growth temperature of $84.7^{\circ} \mathrm{C}$. It also is phylogenetically similar to the members of the Deinococcus-Thermus clade, which is interesting giving the high concentrations of Meiothermus, a similar genera, in the wells. The proposed metabolism of 'A. autotrophicum' is acetogenesis through the acteyl $\mathrm{CoA}$ pathway utilizing $\mathrm{CO}_{2}$ and $\mathrm{H}_{2}$, which is an ancient C-fixation pathway (Takami et al., 2012). Candidate phyla by definition are phyla with no cultured and formally described representative strains, so little to nothing is known about their metabolic requirements and physiology. Future microbiological studies of Oman subsurface fluids may provide more insight into the function of these organisms, particularly if they can be cultured and studied in the laboratory.

A diverse range of phyla were identified from the well fluids. Clostridia and Hydrogenophaga are abundant in the fluids, supporting the idea that previous studies probing hyperalkaline seeps were identifying organisms that are indeed present in the subsurface (Brazelton et al., 2013; Suzuki et al., 2013). The Hydrogenophaga sequences detected here were $100 \%$ identical to Serpentinomonas (Suzuki et al., 2014), a bacterium cultured and characterized from the Cedars ophiolite. This organism is an obligate alkaliphile with an optimum growth $\mathrm{pH}$ of 11 . It utilizes $\mathrm{H}_{2}, \mathrm{CaCO}_{3}$, and $\mathrm{O}_{2}$ for growth. Clostridia, specifically members of the Erysipelothrix group, found in these samples were also found in the Tablelands Ophiolite, and this group is known to contain abundant fermentation-associated hydrogenases, suggesting that it uses organic compounds to survive (Brazelton et al., 2013). Lipids extracted from brucite-calcite veins at the Iberia margin, a Lost-City type hydrothermal field, are also hypothesized to correspond to Desulfotomaculum and Clostridium (Klein et al., 2015); thus, Clostridia are widespread in serpentinizing systems. Additionally, these anaerobic organisms contain [FeFe]-hydrogenases that can catalyze hydrogen production from the reduction of organic materials like acetate and formate (Brazelton et al., 2012). Clostridia are also endspore-forming, which may allow them to persist in these fluids during nutrient-poor periods (Madigan, 2012).

The metabolic pathways of the 16S rRNA correspond to predictions of potential metabolisms in the fluids that are derived from the in-situ geochemistry. Chloroflexi have a range of metabolic strategies which include fermentation, $\mathrm{CO}_{2}$ fixation, and acetogenesis (Hug et al., 2013). Thermodesulfovibrionaceaea is a sulfate-reducer, and some species of Clostridia may also be 
capable of sulfate reduction (Madigan, 2012). There are several Gammaproteobacteria in the fluids that may be denitrifiers (e.g. the extensively studied Psuedomonoas stutzeri) (Madigan, 2012). The other predicted metabolisms, such as methane oxidation and sulfate reduction, may

933 be facilitated by Methylococcales and Desulfovibrionales.

934 The two wells host different microbial communities. This is most likely dictated by the varying geochemistry and $\mathrm{pH}$ between the subsurface systems. NSHQ04 has a lower $\mathrm{pH}(10.5)$ and more electron acceptors such as nitrate and sulfate to make it more habitable and diverse. NSHQ04 also has higher concentrations of $\mathrm{CH}_{4}$ than NSHQ14, which is reflected in the fact it contains methane oxidizers. Although our method of 16S rRNA amplicon sequencing does not reflect the quantity of organisms in the system, it does reveal that geochemistry strongly modulates microbial ecology in hyperalkaline subsurface fluids.

942 The well fluids from 2012 are carbon-poor with DIC concentrations that vary from 0.078 $9430.391 \mathrm{mM}$. It is possible that the highly reducing conditions produced by high levels of $\mathrm{H}_{2}$ in serpentinizing environments lead to the abiogenic formation of low weight molecular acids (Lang et al., 2010; Schrenk et al., 2013). McCollom and Seewald (2001) observed formation of formate during $300^{\circ} \mathrm{C}$ olivine serpentinization experiments:

\subsection{Carbon sources in hyperalkaline fluids}

High concentrations of formate $(36-158 \mu \mathrm{m} / \mathrm{kg})$ are observed at the Lost City Hydrothermal Field, and isotopic data suggest that the formate formed abiotically (Proskurowski et al., 2006; Lang et al., 2010). However, low molecular weight organic acids were not detected above the micromolar detection limit for the species measured in our samples, suggesting that they are not extensively produced under in-situ conditions. Alternatively, the absence of formate and other organic acids could be due to their rapid consumption by subsurface microorganisms.

We searched for complex organic carbon in the Oman drill cuttings as a potential carbon source and indicator of microbial life, but no accumulations of macromolecular carbon were detected in the well chips by Raman spectroscopy. Raman spectroscopic mapping has successfully been used to search for signs of life within serpentinized peridotites from the Mid-Atlantic Ridge, where complex organic carbon has been found in association with cavities in hydroandraditic garnets (Ménez et al., 2012). These hollow cavities are thought to host cryptoendolithic microbes, metabolizing $\mathrm{H}_{2}$ generated through serpentinization or using $\mathrm{Fe}(\mathrm{III})$ in garnets as an oxidant for $\mathrm{H}_{2}$. Complex organic molecules from these organisms might then migrate into the surrounding serpentines and ocean, providing a source of carbon for other microbial life (Pasini et al., 2013).

We also measured total organic carbon (TOC) in the drill cuttings through combustion techniques, but the results are likely overestimates because residual magnesite may be present (Supplementary Table 1). Organic carbon could derive from a rock-hosted biome, but these concentrations of organic carbon could also be a relic of drilling contamination or abiotic reduction of $\mathrm{CO}_{2}$. Further information about molecular structure and distribution of organic carbon are necessary to characterize its source. 
972 Heavily altered Oman peridotites contain extensive carbonate vein networks (Kelemen and 973 Matter, 2008; Kelemen et al., 2011; Streit et al., 2012; Paukert et al., 2012; Mervine et al., 2014)

974 which may provide an unconventional carbon source to microorganisms in the subsurface. 975 Previous work by Suzuki et al. (2014) shows the Serpentinomonas can utilize $\mathrm{CaCO}_{3}$ as a carbon 976 source. However, we do not detect the presence of carbonate veins in the drill cuttings, but they 977 are most likely a small component (aqueous carbonic acid was not measured) so would not be 978 easily detected by bulk powder XRD. We did a simple test for carbonate by adding $\mathrm{HCl}$ and 979 measuring change in mass and observe about $1 \%$ carbonate in the drill cuttings; this is also a low 980 estimate, since the analysis is neglecting to measure magnesite. Thus, carbonate veins in the 981 rocks may be a carbon source for organisms in the subsurface.

982 Finally, Type I, $\mathrm{Mg}-\mathrm{HCO}_{3}$-rich waters are abundant in Oman, and contain 1-10 mM total carbon 983 (e.g., compiled data in Supplement of Kelemen and Matter, 2008). Type I waters could supply 984 carbon for growth of micro-organisms by infiltration into more heavily reacted rocks hosting 985 Type II waters. 


\section{Conclusions}

987 Subsurface mantle peridotites from the Samail Ophiolite in Oman are highly serpentinized and 988 oxidized, and are in contact with hyperalkaline ( $>\mathrm{pH} 10)$ fluids high in $\mathrm{Ca}^{2+}, \mathrm{OH}^{-}$, dissolved $\mathrm{H}_{2}$ and $\mathrm{CH}_{4}$. High concentrations of very negative $\delta \mathrm{D} \mathrm{H}_{2}$ values are inferred to have formed or equilibrated at $\sim 50^{\circ} \mathrm{C}$. The coupled $\delta \mathrm{D}$ and positive $\delta^{13} \mathrm{C}$ of the dissolved $\mathrm{CH}_{4}$ would $992 \mathrm{CH}_{4}$ reported in the literature thus far. We suggest that the methane isotopic signature is in part 993 modulated by significant oxidation, whether it was produced through biotic or abiotic pathways.

994 We hypothesize that these gas-rich hyperalkaline fluids have evolved through an ongoing stage 995 of low temperature serpentinization in the peridotite. Olivine hydration during early 996 hydrothermal alteration and obduction formed Fe(II,III) serpentine, $\mathrm{Fe}(\mathrm{II})$ brucite and hydrogen. 997 During the current phase of low temperature water/rock interaction, brucite is destabilized in the fluids with high $\mathrm{SiO}_{2}$ activity, generating $\mathrm{H}_{2}$ when it is converted to magnetite and additional $\mathrm{Fe}(\mathrm{III})$-rich serpentine. The relict olivine is also further reacting to form $\mathrm{Fe}(\mathrm{III})$-rich serpentine and hydrogen. The formation mechanism for methane remains enigmatic, and could involve low temperature abiotic $\mathrm{CO}_{2}$ reduction by mineral catalysts, or in-situ biological activity.

Our study of drill cuttings and fluids reveals that the timing and extent of various stages of

1003 serpentinization in Oman remain unconstrained. It is difficult to tease apart mineral parageneses formed during hydrothermal alteration near an oceanic spreading ridge, emplacement of the ophiolite, Late Cretaceous weathering, and modern water/rock reactions. Future studies that can connect rock alteration histories along reaction paths with varying fluid sources and residence times will be a valuable next step in assessing the mechanisms and extent of modern, lowtemperature $\mathrm{H}_{2}$ and $\mathrm{CH}_{4}$ generation. Continuous physical and magnetic properties measurements downhole and on bulk core samples will help delineating sections with hydrology in situ where serpentinization has been extensive.

1011 16s rRNA data of DNA extracted from the hyperalkaline fluid microbial communities indicate 1012 an abundance of both aerobic and anaerobic organisms, including abundant Meiothermus, 1013 Thermodesulfovibrionaceae (sulfate-reducers), Clostridia (fermentors), and Hydrogenophaga 1014 ( $\mathrm{H}_{2}$-oxidizers). Although not abundant, methanogen Methanobacterium and candidate phylum OP1 are also notably present. We hypothesize that the subsurface microbial communities are harnessing the $\mathrm{H}_{2}$ produced by water/rock reactions, and coupling the oxidation of $\mathrm{H}_{2}$ to electron acceptors such as $\mathrm{SO}_{4}{ }^{2-}, \mathrm{CO}_{2}$ and $\mathrm{Fe}(\mathrm{III})$-bearing phases at depth, and episodically with $\mathrm{O}_{2}$ and 1018 nitrate in the upper fractured part of the aquifer.

1019 Probing the microbial community composition in these fluids provides a first glimpse into the 1020 complex subsurface peridotite-hosted microbiome. The rock-hosted communities may be quite different than those established in the fluids, due to strong gradients in redox potential, electron acceptor and donor availability, porosity, permeability, fluid residence times, and mineral reactivity. Moreover, this initial 16S rRNA gene sequence data are just an initial perspective within the broader efforts to fully understand feedbacks between microbial activity, aqueous geochemistry and mineralogy. Isolating and culturing the peridotite-hosted organisms will be an important step in understanding their true metabolic activities and how they adapt to the carbondepleted, hyperalkaline fluid environment. The microorganisms may be utilizing carbonate veins as a carbon source, leading to mineral dissolution and potential methane production. 
1029 Additionally, microbial consumption of hydrogen from water/rock reactions may increase the 1030 rate of hydrogen-producing reactions. Furthermore, in-situ microbes may be generating distinct 1031 organic, mineral and/or isotopic biosignatures in serpentinizing environments that can be used to 1032 identify microbial activity remotely.

1033 Examining the functional activity of microbial life in the subsurface will be important to fully 1034 understand the coupling between the water/rock reactions, production of reduced gases, and 1035 changes in aquifer chemistry and hydrology. A next step for studying the coupling between the 1036 hydrological and geochemical processes and the distribution and activity of subsurface microbial 1037 life will be to focus on process rate measurements of in-situ hydrogen generation and 1038 consumption, pathways of $\mathrm{C}$ assimilation and uptake, and rates of methanogenesis, sulfate 1039 reduction, and nitrate reduction. Intensive culturing of peridotite-adapted microorganisms in the 1040 laboratory will also be necessary to elucidate the operative metabolic pathways. All of these 1041 efforts will be greatly facilitated by the International Continental Drilling Program (ICDP) 1042 project in Oman (https://www.ldeo.columbia.edu/gpg/projects/icdp-workshop-oman-drilling1043 project). The results from this scientific endeavor will give further insight into predicted 1044 mineralogy, microbiology, gas generation and C cycling of planetary systems undergoing active 1045 alteration of peridotite in the shallow subsurface. 
1046 Acknowledgements: The authors would like to thank Tori Hoehler and Mike Kubo (NASA

1047 Ames) for providing exploratory organic acid analyses; Said Nasser Al-Habsi and Salim

1048 Mohammed Al Khanbashi of the Ministry of Regional Municipalities and Water Resources

1049 Sultanate of Oman for granting access to well fluids and drill cuttings; Amelia Paukert for

1050 providing supporting information and samples. We would also like to thank numerous colleagues

1051 at the University of Colorado at Boulder: Julien Allaz and the electron microprobe lab, the

1052 Raman lab, Fred Luiszer at the Laboratory for Environmental and Geological Studies, the Barger

1053 lab with their total organic carbon analyzer, the Fierer lab for their sequencing help, Lisa

1054 Mayhew for valued discussions and Kaitlin Rempfert for help collecting samples in 2015.

1055 Raman imaging and spectroscopy was conducted at the Raman Microspectroscopy Laboratory at

1056 the Department of Geological Sciences, University of Colorado-Boulder. Use of the Stanford

1057 Synchrotron Radiation Lightsource, SLAC National Accelerator Laboratory, is supported by the

1058 U.S. Department of Energy, Office of Science, Office of Basic Energy Sciences under Contract

1059 No. DE-AC02-76SF00515, in collaboration with staff scientists Sam Webb, Courtney Krest, and

1060 Ryan Davis. This research was funded by the Department of Energy (DE-SC0006886), the

1061 University of Colorado, the NASA Astrobiology Institute (Cooperative Agreement

1062 NNA15BB02A), Alfred P. Sloan Foundation Grant 2014-3-01, and NSF EAR-1049905.

1063

1064 


\section{References}

1066

1067

1068

1069

1070

1071

1072

1073

1074

1075

1076

1077

1078

1079

1080

1081

1082

1083

1084

1085

1086

1087

1088

1089

1090

1091

1092

1093

1094

1095

1096

1097
Abrajano T. A., Sturchio N. C., Kennedy B. M., Lyon G. L., Muehlenbachs K. and Bohlke J. K. (1990) Geochemistry of reduced gas related to serpentinization of the Zambales ophiolite, Philippines. Appl. Geochem. 5, 625-630.

Anderson R. T., Chapelle F. H. and Lovley D. R. (1998) Evidence Against Hydrogen-Based Microbial Ecosystems in Basalt Aquifers. Science 281, 976-977.

Andreani M., Muñoz M., Marcaillou C. and Delacour A. (2013a) $\mu$ XANES study of iron redox state in serpentine during oceanic serpentinization. Lithos 178, 70-83.

Andreani M., Muñoz M., Marcaillou C. and Delacour A. (2013b) $\mu$ XANES study of iron redox state in serpentine during oceanic serpentinization. Lithos 178, 70-83.

Bach W., Paulick H., Garrido C. J., Ildefonse B., Meurer W. P. and Humphris S. E. (2006) Unraveling the sequence of serpentinization reactions: petrography, mineral chemistry, and petrophysics of serpentinites from MAR $15^{\circ} \mathrm{N}$ (ODP Leg 209, Site 1274). Geophys. Res. Lett. 33. Available at: http://doi.wiley.com/10.1029/2006GL025681 [Accessed May $19,2015]$.

Balch W. E., Fox G. E., Magrum L. J., Woese C. R. and Wolfe R. S. (1979) Methanogens: reevaluation of a unique biological group. Microbiol. Rev. 43, 260-296.

Barberán A., Ladau J., Leff J. W., Pollard K. S., Menninger H. L., Dunn R. R. and Fierer N. (2015) Continental-scale distributions of dust-associated bacteria and fungi. Proc. Natl. Acad. Sci. 112, 5756-5761.

Barnes I., LaMarche V. C. and Himmelberg G. (1967) Geochemical Evidence of Present-Day Serpentinization. Science 156, 830-832.

Barnes I. and O’Neil J. R. (1969) The Relationship between Fluids in Some Fresh Alpine-Type Ultramafics and Possible Modern Serpentinization, Western United States. Geol. Soc. Am. Bull. 80, 1947-1960.

Barnes I., O’Neil J. R. and Trescases J. J. (1978) Present day serpentinization in New Caledonia, Oman and Yugoslavia. Geochim. Cosmochim. Acta 42, 144-145.

Bottinga Y. (1969) Calculated fractionation factors for carbon and hydrogen isotope exchange in the system calcite-carbon dioxide-graphite-methane-hydrogen-water vapor. Geochim. Cosmochim. Acta 33, 49-64.

Boudier F., Baronnet A. and Mainprice D. (2010) Serpentine Mineral Replacements of Natural Olivine and their Seismic Implications: Oceanic Lizardite versus Subduction-Related Antigorite. J. Petrol. 51, 495-512. 
1098

1099

1100

1101

1102

1103

1104

1105

1106

1107

1108

1109

1110

1111

1112

1113

1114

1115

1116

1117

1118

1119

1120

1121

1122

1123

1124

1125

1126

1127

1128

1129

1130

1131

1132

1133

1134

Bowers R. M., Clements N., Emerson J. B., Wiedinmyer C., Hannigan M. P. and Fierer N. (2013) Seasonal Variability in Bacterial and Fungal Diversity of the Near-Surface Atmosphere. Environ. Sci. Technol. 47, 12097-12106.

Brazelton W. J., Morrill P. L., Szponar N. and Schrenk M. O. (2013) Bacterial Communities Associated with Subsurface Geochemical Processes in Continental Serpentinite Springs. Appl. Environ. Microbiol. 79, 3906-3916.

Brazelton W. J., Nelson B. and Schrenk M. O. (2012) Metagenomic Evidence for H2 Oxidation and $\mathrm{H} 2$ Production by Serpentinite-Hosted Subsurface Microbial Communities. Front. Microbiol. 2. Available at: http://www.frontiersin.org/Journal/10.3389/fmicb.2011.00268/full [Accessed January 30, 2014].

Bruni J., Canepa M., Chiodini G., Cioni R., Cipolli F., Longinelli A., Marini L., Ottonello G. and Vetuschi Zuccolini M. (2002) Irreversible water-rock mass transfer accompanying the generation of the neutral, $\mathrm{Mg}-\mathrm{HCO} 3$ and high- $\mathrm{pH}, \mathrm{Ca}-\mathrm{OH}$ spring waters of the Genova province, Italy. Appl. Geochem. 17, 455-474.

Butler R. and Banerjee S. (1975) Theoretical Single-Domain Grain Size Range m Magnetite and Titanomagnetite. J. Geophys. Res., 4049-4058.

Cardace D. and Hoehler T. M. (2009) Serpentinizing Fluids Craft Microbial Habitat. Northeast. Nat. 16, 272-284.

Cardace D., Meyer-Dombard D. R., Woycheese K. M. and Arcilla C. A. (2015) Feasible metabolisms in high pH springs of the Philippines. Front. Microbiol. 6. Available at: http://journal.frontiersin.org/Article/10.3389/fmicb.2015.00010/abstract [Accessed May $21,2015]$.

Chapelle F. H., O’Neill K., Bradley P. M., Methé B. A., Ciufo S. A., Knobel L. L. and Lovley D. R. (2002) A hydrogen-based subsurface microbial community dominated by methanogens. Nature 415, 312-315.

Chavagnac V., Ceuleneer G., Monnin C., Lansac B., Hoareau G. and Boulart C. (2013) Mineralogical assemblages forming at hyperalkaline warm springs hosted on ultramafic rocks: A case study of Oman and Ligurian ophiolites. Geochem. Geophys. Geosystems 14, 2474-2495.

Chavagnac V., Monnin C., Ceuleneer G., Boulart C. and Hoareau G. (2013) Characterization of hyperalkaline fluids produced by low-temperature serpentinization of mantle peridotites in the Oman and Ligurian ophiolites. Geochem. Geophys. Geosystems 14, 2496-2522.

Clark I. D. and Fontes J.-C. (1990) Paleoclimatic reconstruction in northern Oman based on carbonates from hyperalkaline groundwaters. Quat. Res. 33, 320-336.

Coleman R. G. (1981) Tectonic setting for ophiolite obduction in Oman. J. Geophys. Res. Solid Earth 86, 2497-2508. 
1135

1136

1137

1138

1139

1140

1141

1142

1143

1144

1145

1146

1147

1148

1149

1150

1151

1152

1153

1154

1155

1156

1157

1158

1159

1160

1161

1162

1163

1164

1165

1166

1167

1168

1169
Dewandel B., Lachassagne P., Boudier F., Al-Hattali S., Ladouche B., Pinault J.-L. and A1Suleimani Z. (2005) A conceptual hydrogeological model of ophiolite hard-rock aquifers in Oman based on a multiscale and a multidisciplinary approach. Hydrogeol. J. 13, 708726.

Dunlop D. J. (1973) Superparamagnetic and single-domain threshold sizes in magnetite. J. Geophys. Res. 78, 1780-1793.

Edgar R. C. (2013) UPARSE: highly accurate OTU sequences from microbial amplicon reads. Nat. Methods 10, 996-8.

Emerson J. B., Keady P. B., Brewer T. E., Clements N., Morgan E. E., Awerbuch J., Miller S. L. and Fierer N. (2015) Impacts of Flood Damage on Airborne Bacteria and Fungi in Homes after the 2013 Colorado Front Range Flood. Environ. Sci. Technol. 49, 2675-2684.

Etiope G., Ehlmann B. L. and Schoell M. (2013) Low temperature production and exhalation of methane from serpentinized rocks on Earth: A potential analog for methane production on Mars. Icarus 224, 276-285.

Etiope G., Schoell M. and Hosgörmez H. (2011) Abiotic methane flux from the Chimaera seep and Tekirova ophiolites (Turkey): Understanding gas exhalation from low temperature serpentinization and implications for Mars. Earth Planet. Sci. Lett. 310, 96-104.

Etiope G. and Sherwood Lollar B. (2013) Abiotic Methane on Earth. Rev. Geophys. 51, 276299.

Evans B. W. (2010) Lizardite versus antigorite serpentinite: Magnetite, hydrogen, and life (?). Geology 38, 879-882.

Evans B. W. (2004) The Serpentinite Multisystem Revisited: Chrysotile Is Metastable. Int. Geol. Rev. 46, 479-506.

Evans B. W., Kuehner S. M. and Chopelas A. (2009) Magnetite-free, yellow lizardite serpentinization of olivine websterite, Canyon Mountain complex, N.E. Oregon. Am. Mineral. 94, 1731-1734.

Frost B. R. (1985) On the stability of sulfides, oxides, and native metals in serpentinite. J. Petrol. 26, 31-63.

Frost B. R. and Beard J. S. (2007) On Silica Activity and Serpentinization. J. Petrol. 48, 13511368.

Groppo C., Rinaudo C., Cairo S., Gastaldi D. and Compagnoni R. (2006) Micro-Raman spectroscopy for a quick and reliable identification of serpentine minerals from ultramafics. Eur. J. Mineral. 18, 319-329.

Hanghøj K., Kelemen P. B., Hassler D. and Godard M. (2010) Composition and Genesis of Depleted Mantle Peridotites from the Wadi Tayin Massif, Oman Ophiolite; Major and 
Trace Element Geochemistry, and Os Isotope and PGE Systematics. J. Petrol. 51, 201227.

Haouari O., Fardeau M.-L., Cayol J.-L., Fauque G., Casiot C., Elbaz-Poulichet F., Hamdi M. and Ollivier B. (2008) Thermodesulfovibrio hydrogeniphilus sp. nov., a new thermophilic sulphate-reducing bacterium isolated from a Tunisian hot spring. Syst. Appl. Microbiol. 31, 38-42.

Haroon M. F., Hu S., Shi Y., Imelfort M., Keller J., Hugenholtz P., Yuan Z. and Tyson G. W. (2013) Anaerobic oxidation of methane coupled to nitrate reduction in a novel archaeal lineage. Nature 500, 567-570.

Hicks D. B., Liu J., Fujisawa M. and Krulwich T. A. (2010) F1F0-ATP synthases of alkaliphilic bacteria: Lessons from their adaptations. Biochim. Biophys. Acta BBA - Bioenerg. 1797, 1362-1377.

Hoehler T. M., Alperin M. J., Albert D. B. and Martens C. S. (1994) Field and laboratory studies of methane oxidation in an anoxic marine sediment: Evidence for a methanogen-sulfate reducer consortium. Glob. Biogeochem. Cycles 8, 451-463.

Horibe Y. and Craig H. (1995) DH fractionation in the system methane-hydrogen-water. Geochim. Cosmochim. Acta 59, 5209-5217.

Horita J. and Berndt M. E. (1999) Abiogenic Methane Formation and Isotopic Fractionation Under Hydrothermal Conditions. Science 285, 1055-1057.

Hug L. A., Castelle C. J., Wrighton K. C., Thomas B. C., Sharon I., Frischkorn K. R., Williams K. H., Tringe S. G. and Banfield J. F. (2013) Community genomic analyses constrain the distribution of metabolic traits across the Chloroflexi phylum and indicate roles in sediment carbon cycling. Microbiome 1, 22.

Jacquemin M., Beuls A. and Ruiz P. (2010) Catalytic production of methane from CO2 and $\mathrm{H} 2$ at low temperature: Insight on the reaction mechanism. Catal. Today 157, 462-466.

Joye S. B., Boetius A., Orcutt B. N., Montoya J. P., Schulz H. N., Erickson M. J. and Lugo S. K. (2004) The anaerobic oxidation of methane and sulfate reduction in sediments from Gulf of Mexico cold seeps. Chem. Geol. 205, 219-238.

Kelemen P. B. and Hirth G. (2012) Reaction-driven cracking during retrograde metamorphism: Olivine hydration and carbonation. Earth Planet. Sci. Lett. 345-348, 81-89.

Kelemen P. B. and Matter J. (2008) In situ carbonation of peridotite for CO2 storage. Proc. Natl. Acad. Sci. 105, 17295-17300.

Kelemen P. B., Matter J., Streit E. E., Rudge J. F., Curry W. B. and Blusztajn J. (2011) Rates and Mechanisms of Mineral Carbonation in Peridotite: Natural Processes and Recipes for Enhanced, in situ CO2 Capture and Storage. Annu. Rev. Earth Planet. Sci. 39, 545-576. 
Klein F., Bach W., Humphris S. E., Kahl W.-A., Jons N., Moskowitz B. and Berquo T. S. (2013) Magnetite in seafloor serpentinite--Some like it hot. Geology 42, 135-138.

Klein F., Bach W., Jöns N., McCollom T., Moskowitz B. and Berquó T. (2009) Iron partitioning and hydrogen generation during serpentinization of abyssal peridotites from $15^{\circ} \mathrm{N}$ on the Mid-Atlantic Ridge. Geochim. Cosmochim. Acta 73, 6868-6893.

Klein F., Bach W. and McCollom T. M. (2013) Compositional controls on hydrogen generation during serpentinization of ultramafic rocks. Lithos 178, 55-69.

Klein F., Humphris S. E., Guo W., Schubotz F., Schwarzenbach E. M. and Orsi W. D. (2015) Fluid mixing and the deep biosphere of a fossil Lost City-type hydrothermal system at the Iberia Margin. Proc. Natl. Acad. Sci., 201504674.

Kumar M. R. and Saravanan V. S. (2011) Candidate OP Phyla: Importance, Ecology and Cultivation Prospects. Indian J. Microbiol. 50, 474-477.

Lafay R., Montes-Hernandez G., Janots E., Chiriac R., Findling N. and Toche F. (2012) Mineral replacement rate of olivine by chrysotile and brucite under high alkaline conditions. $J$. Cryst. Growth 347, 62-72.

Laier T. and Nytoft H. P. (2012) Bitumen biomarkers in the Mid-Proterozoic Ilímaussaq intrusion, Southwest Greenland - A challenge to the mantle gas theory. Mar. Pet. Geol. 30, 50-65.

Lang S. Q., Butterfield D. A., Schulte M., Kelley D. S. and Lilley M. D. (2010) Elevated concentrations of formate, acetate and dissolved organic carbon found at the Lost City hydrothermal field. Geochim. Cosmochim. Acta 74, 941-952.

Lorand J. (1987) A New Occurrence of Native Iron in a Serpentinized Mantle Peridotite Maqsad, Sumail Massif, Semail Ophiolite (Southern Oman). Comptes Rendus Acad. Sci. Ii 304, 703-6.

Madigan M. T. (2012) Brock biology of microorganisms., Benjamin Cummings, San Francisco.

Malvoisin B., Carlut J. and Brunet F. (2012) Serpentinization of oceanic peridotites: 1. A highsensitivity method to monitor magnetite production in hydrothermal experiments. $J$. Geophys. Res. Solid Earth 117, B01104.

Marcaillou C., Muñoz M., Vidal O., Parra T. and Harfouche M. (2011) Mineralogical evidence for $\mathrm{H} 2$ degassing during serpentinization at $300{ }^{\circ} \mathrm{C} / 300$ bar. Earth Planet. Sci. Lett. 303, 281-290.

Mayhew L. E., Ellison E. T., McCollom T. M., Trainor T. P. and Templeton A. S. (2013) Hydrogen generation from low-temperature water-rock reactions. Nat. Geosci. 6, 478484. 
Mayhew L. E., Webb S. M. and Templeton A. S. (2011) Microscale Imaging and Identification of Fe Speciation and Distribution during Fluid-Mineral Reactions under Highly Reducing Conditions. Environ. Sci. Technol. 45, 4468-4474.

McCollom T. M. and Bach W. (2009) Thermodynamic constraints on hydrogen generation during serpentinization of ultramafic rocks. Geochim. Cosmochim. Acta 73, 856-875.

McCollom T. M. and Seewald J. S. (2001) A reassessment of the potential for reduction of dissolved $\mathrm{CO} 2$ to hydrocarbons during serpentinization of olivine. Geochim. Cosmochim. Acta 65, 3769-3778.

McDonald D., Price M. N., Goodrich J., Nawrocki E. P., DeSantis T. Z., Probst A., Andersen G. L., Knight R. and Hugenholtz P. (2012) An improved Greengenes taxonomy with explicit ranks for ecological and evolutionary analyses of bacteria and archaea. ISME J. 6, 610-8.

Ménez B., Pasini V. and Brunelli D. (2012) Life in the hydrated suboceanic mantle. Nat. Geosci. 5, 133-137.

Mervine E. M., Humphris S. E., Sims K. W. W., Kelemen P. B. and Jenkins W. J. (2014) Carbonation rates of peridotite in the Samail Ophiolite, Sultanate of Oman, constrained through 14C dating and stable isotopes. Geochim. Cosmochim. Acta 126, 371-397.

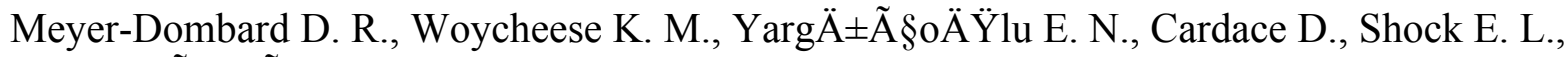

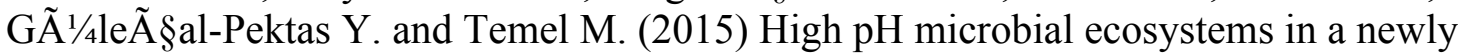
discovered, ephemeral, serpentinizing fluid seep at YanartaÅŸ (Chimera), Turkey. Front. Microbiol. 5. Available at: http://journal.frontiersin.org/article/10.3389/fmicb.2014.00723/abstract [Accessed March 7, 2015].

Moody J. B. (1976) Serpentinization: a review. Lithos 9, 125-138.

Morrill P. L., Kuenen J. G., Johnson O. J., Suzuki S., Rietze A., Sessions A. L., Fogel M. L. and Nealson K. H. (2013) Geochemistry and geobiology of a present-day serpentinization site in California: The Cedars. Geochim. Cosmochim. Acta 109, 222-240.

Mulkidjanian A. Y., Dibrov P. and Galperin M. Y. (2008) The past and present of sodium energetics: May the sodium-motive force be with you. Biochim. Biophys. Acta BBA Bioenerg. 1777, 985-992.

Muñoz M., Vidal O., Marcaillou C., Pascarelli S., Mathon O. and Farges F. (2013) Iron oxidation state in phyllosilicate single crystals using Fe-K pre-edge and XANES spectroscopy: Effects of the linear polarization of the synchrotron X-ray beam. Am. Mineral. 98, 1187-1197.

Neal C. and Stanger G. (1984) Calcium and magnesium hydroxide precipitation from alkaline groundwaters in Oman, and their significance to the process of serpentinization. Miner. Mag 48, 237-241. 
1275

Neal C. and Stanger G. (1983) Hydrogen generation from mantle source rocks in Oman. Earth Planet. Sci. Lett. 66, 315-320.

Neal C. and Stanger G. (1985) Past And Present Serpentinisation of Ultramafic Rocks; An Example from the Semail Ophiolite Nappe of Northern Oman. In The Chemistry of Weathering (ed. J. I. Drever). Nato ASI Series. Springer Netherlands. pp. 249-275. Available at: http://link.springer.com/chapter/10.1007/978-94-009-5333-8_15 [Accessed June 17, 2015].

Nealson K. H., Inagaki F. and Takai K. (2005) Hydrogen-driven subsurface lithoautotrophic microbial ecosystems (SLiMEs): do they exist and why should we care? Trends Microbiol. 13, 405-410.

Neubeck A., Duc N. T., Bastviken D., Crill P. and Holm N. G. (2011) Formation of H2 and CH4 by weathering of olivine at temperatures between 30 and 70 C. Geochem. Trans. 12, 6.

Nielsen J. L. and Nielsen P. H. (1998) Microbial Nitrate-Dependent Oxidation of Ferrous Iron in Activated Sludge. Environ. Sci. Technol. 32, 3556-3561.

Okland I., Huang S., Dahle H., Thorseth I. H. and Pedersen R. B. (2012) Low temperature alteration of serpentinized ultramafic rock and implications for microbial life. Chem. Geol. 318-319, 75-87.

Pasini V., Brunelli D., Dumas P., Sandt C., Frederick J., Benzerara K., Bernard S. and Ménez B. (2013) Low temperature hydrothermal oil and associated biological precursors in serpentinites from Mid-Ocean Ridge. Lithos 178, 84-95.

Paukert A. N., Matter J. M., Kelemen P. B., Shock E. L. and Havig J. R. (2012) Reaction path modeling of enhanced in situ $\mathrm{CO} 2$ mineralization for carbon sequestration in the peridotite of the Samail Ophiolite, Sultanate of Oman. Chem. Geol. 330-331, 86-100.

Petriglieri J. R., Salvioli-Mariani E., Mantovani L., Tribaudino M., Lottici P. P., Laporte-Magoni C. and Bersani D. (2015) Micro-Raman mapping of the polymorphs of serpentine. $J$. Raman Spectrosc., n/a-n/a.

Postec A., Quéméneur M., Bes M., Mei N., Benaïssa F., Payri C., Pelletier B., Monnin C., Guentas-Dombrowsky L., Ollivier B., Gérard E., Pisapia C., Gérard M., Ménez B. and Erauso G. (2015) Microbial diversity in a submarine carbonate edifice from the serpentinizing hydrothermal system of the Prony Bay (New Caledonia) over a 6-year period. Front. Microbiol. 6. Available at: http://www.ncbi.nlm.nih.gov/pmc/articles/PMC4551099/ [Accessed November 20, 2015].

Proskurowski G., Lilley M. D., Kelley D. S. and Olson E. J. (2006) Low temperature volatile production at the Lost City Hydrothermal Field, evidence from a hydrogen stable isotope geothermometer. Chem. Geol. 229, 331-343. 
1311

1312

1313

1314

1315

1316

1317

1318

1319

1320

1321

1322

1323

1324

1325

1326

1327

1328

1329

1330

1331

1332

1333

1334

1335

1336

1337

1338

1339

1340

1341

1342

1343

1344

1345

1346

R Development Core Team (2008) R: A language and environment for statistical computing., $\mathrm{R}$ Foundation for Statistical Computing, Vienna, Austria. Available at: http://www.Rproject.org.

Ravaut P., Bayer R., Hassani R., Rousset D. and Yahya'ey A. A. (1997) Structure and evolution of the northern Oman margin: gravity and seismic constraints over the Zagros-MakranOman collision zone. Tectonophysics 279, 253-280.

Rinaudo C., Gastaldi D. and Belluso E. (2003) Characterization of Chrysotile, Antigorite and Lizardite by Ft-Raman Spectroscopy. Can. Mineral. 41, 883-890.

Schrenk M. O., Brazelton W. J. and Lang S. Q. (2013) Serpentinization, Carbon, and Deep Life. Rev. Mineral. Geochem. 75, 575-606.

Sherwood Lollar B., Frape S. K., Weise S. M., Fritz P., Macko S. A. and Welhan J. A. (1993) Abiogenic methanogenesis in crystalline rocks. Geochim. Cosmochim. Acta 57, 50875097.

Sleep N. H., Meibom A., Fridriksson T., Coleman R. G. and Bird D. K. (2004) H2-rich fluids from serpentinization: geochemical and biotic implications. Proc. Natl. Acad. Sci. U. S. A. 101, 12818-12823.

Stanger G. (1986) The hydrogeology of the Oman Mountains. Open University London.

Stevens T. O. and McKinley J. P. (2000) Abiotic Controls on $\mathrm{H}_{2}$ Production from Basalt-Water Reactions and Implications for Aquifer Biogeochemistry. Environ. Sci. Technol. 34, 826831.

Stevens T. O. and McKinley J. P. (1995) Lithoautotrophic Microbial Ecosystems in Deep Basalt Aquifers. Science 270, 450-455.

Streit E., Kelemen P. and Eiler J. (2012) Coexisting serpentine and quartz from carbonatebearing serpentinized peridotite in the Samail Ophiolite, Oman. Contrib. Mineral. Petrol. 164, 821-837.

Suzuki S., Ishii S., Wu A., Cheung A., Tenney A., Wanger G., Kuenen J. G. and Nealson K. H. (2013) Microbial diversity in The Cedars, an ultrabasic, ultrareducing, and low salinity serpentinizing ecosystem. Proc. Natl. Acad. Sci. 110, 15336-15341.

Suzuki S., Kuenen J. G., Schipper K., van der Velde S., Ishii S., Wu A., Sorokin D. Y., Tenney A., Meng X., Morrill P. L., Kamagata Y., Muyzer G. and Nealson K. H. (2014) Physiological and genomic features of highly alkaliphilic hydrogen-utilizing Betaproteobacteria from a continental serpentinizing site. Nat. Commun. 5. Available at: http://www.nature.com/ncomms/2014/140521/ncomms4900/full/ncomms4900.html [Accessed November 19, 2014].

Takami H., Noguchi H., Takaki Y., Uchiyama I., Toyoda A., Nishi S., Chee G.-J., Arai W., Nunoura T., Itoh T., Hattori M. and Takai K. (2012) A Deeply Branching Thermophilic 
Bacterium with an Ancient Acetyl-CoA Pathway Dominates a Subsurface Ecosystem. PLoS ONE 7, e30559.

Tauxe L., Banerjee S. K., Butler R. F. and van der Voo R. (2014) Essentials of Paleomagnetism, 3rd Web Edition.

Telling J., Boyd E. S., Bone N., Jones E. L., Tranter M., MacFarlane J. W., Martin P. G., Wadham J. L., Lamarche-Gagnon G., Skidmore M. L., Hamilton T. L., Hill E., Jackson M. and Hodgson D. A. (2015) Rock comminution as a source of hydrogen for subglacial ecosystems. Nat. Geosci. 8, 851-855.

Templeton A. S., Chu K.-H., Alvarez-Cohen L. and Conrad M. E. (2006) Variable carbon isotope fractionation expressed by aerobic $\mathrm{CH} 4$-oxidizing bacteria. Geochim. Cosmochim. Acta 70, 1739-1752.

Tindall B. J., Sikorski J., Lucas S., Goltsman E., Copeland A., Glavina Del Rio T., Nolan M., Tice H., Cheng J.-F., Han C., Pitluck S., Liolios K., Ivanova N., Mavromatis K., Ovchinnikova G., Pati A., Fähnrich R., Goodwin L., Chen A., Palaniappan K., Land M., Hauser L., Chang Y.-J., Jeffries C. D., Rohde M., Göker M., Woyke T., Bristow J., Eisen J. A., Markowitz V., Hugenholtz P., Kyrpides N. C., Klenk H.-P. and Lapidus A. (2010) Complete genome sequence of Meiothermus ruber type strain (21T). Stand. Genomic Sci. 3, 26-36.

Wang Q., Garrity G. M., Tiedje J. M. and Cole J. R. (2007) Naive Bayesian classifier for rapid assignment of rRNA sequences into the new bacterial taxonomy. Appl. Environ. Microbiol. 73, 5261-7.

Weyhenmeyer C. (2000) Origin and evolution of groundwaters in the alluvial aquifer of the Eastern Batinah Coastal Plain, Sultanate of Oman. PhD Thesis Univ. Bern Switz.

Whiticar M. J. (1990) A geochemial perspective of natural gas and atmospheric methane. Org. Geochem. 16, 531-547.

Whiticar M. J. (1999) Carbon and hydrogen isotope systematics of bacterial formation and oxidation of methane. Chem. Geol. 161, 291-314.

Whiticar M. J. and Faber E. (1986) Methane oxidation in sediment and water column environments-Isotope evidence. Org. Geochem. 10, 759-768.

Wilke M., Farges F., Petit P.-E., Brown G. E. and Martin F. (2001) Oxidation state and coordination of Fe in minerals: An Fe K-XANES spectroscopic study. Am. Mineral. 86, 714-730.

Willems A., Busse J., Goor M., Pot B., Falsen E., Jantzen E., Hoste B., Gillis M., Kersters K., Auling G. and others (1989) Hydrogenophaga, a new genus of hydrogen-oxidizing bacteria that includes Hydrogenophaga flava comb. nov.(formerly Pseudomonas flava), Hydrogenophaga palleronii (formerly Pseudomonas palleronii), Hydrogenophaga pseudoflava (formerly Pseudomonas pseudoflava and "Pseudomonas carboxydoflava"), 
and Hydrogenophaga taeniospiralis (formerly Pseudomonas taeniospiralis). Int. J. Syst. Bacteriol. 39, 319-333.

Worm H.-U. (1998) On the superparamagnetic - stable single domain transition for magnetite, and frequency dependence of susceptibility. Geophys. J. Int. 133, 201-206.

Woycheese K. M., Meyer-Dombard D. R., Cardace D., Argayosa A. M. and Arcilla C. A. (2015) Out of the dark: transitional subsurface-to-surface microbial diversity in a terrestrial serpentinizing seep (Manleluag, Pangasinan, the Philippines). Front. Microbiol. 6. Available at: http://journal.frontiersin.org/Article/10.3389/fmicb.2015.00044/abstract [Accessed May 21, 2015]. 
Table 1. Major and minor elements in wells along with $\mathrm{pH}$, temperature, and conductivity. Oman hyperalkaline spring data is from Paukert et al. (2012) sampling Type II surface waters. Oxidation-reduction potential (ORP) data is from sampling the wells in 2012. Gas concentrations were determined by measuring the headspace of anaerobic vials purged with $\mathrm{N}_{2}$ filled with site 1399 water.

\begin{tabular}{|c|c|c|c|c|}
\hline & $\begin{array}{l}\text { NSHQ04 } \\
\text { 18meters }\end{array}$ & $\begin{array}{l}\text { NSHQ14 } \\
\text { 18meters }\end{array}$ & $\begin{array}{l}\text { NSHQ14 } \\
\text { 260meters }\end{array}$ & $\begin{array}{l}\text { Misbit - Oman } \\
\text { hyperalkaline } \\
\text { spring }\end{array}$ \\
\hline $\mathrm{pH}$ & 10.6 & 11.1 & 11.5 & 11.2 \\
\hline Temperature $\left({ }^{\circ} \mathrm{C}\right)$ & 33.3 & 34.3 & 31.5 & 31.6 \\
\hline Conductivity $(\mu \mathrm{S} / \mathrm{m})$ & 2386 & 2430 & 4300 & 1640 \\
\hline ORP $(\mathrm{mV})$ & $-103.4(70 \mathrm{~m})$ & -31.6 & -597.3 & - \\
\hline $\mathrm{Na}^{+}(\mathrm{mM})$ & 12.136 & 12.302 & 6.747 & 2.120 \\
\hline $\mathrm{Ca}^{2+}(\mathrm{mM})$ & 6.424 & 7.604 & 9.001 & 0.017 \\
\hline $\mathrm{Mg}^{2+}(\mathrm{mM})$ & 0.005 & 0.060 & 0.655 & 6.540 \\
\hline $\mathrm{K}^{+}(\mathrm{mM})$ & 0.409 & 0.422 & 0.361 & - \\
\hline $\mathrm{SiO}_{2(\mathrm{aq})}(\mathrm{mM})$ & 0.011 & 0.007 & 0.016 & 0.040 \\
\hline $\mathrm{Cl}^{-}(\mathrm{mM})$ & 24.942 & 25.932 & 21.848 & 6.970 \\
\hline $\mathrm{SO}_{4}{ }^{2-}(\mathrm{mM})$ & 0.483 & 0.190 & 0.050 & 0.070 \\
\hline $\mathrm{NO}_{3}^{-}(\mathrm{mM})$ & 0.012 & 0.022 & 0.016 & $<0.01$ \\
\hline $\mathrm{Br}^{-}(\mathrm{mM})$ & 0.001 & $<0.001$ & 0.001 & - \\
\hline $\mathrm{Al}^{3+}(\mathrm{mM})$ & 0.098 & 0.086 & 0.045 & 0.023 \\
\hline $\mathrm{Fe}^{2+}(\mathrm{mM})$ & $<0.001$ & $<0.001$ & $<0.001$ & $<0.001$ \\
\hline $\mathrm{DIC}(\mathrm{mM})$ & 0.091 & 0.078 & 0.391 & - \\
\hline $\mathrm{H}_{2}(\mathrm{mM})$ & 0.18 & 0.67 & 0.17 & - \\
\hline $\mathrm{CH}_{4}(\mathrm{mM})$ & 1.44 & 0.17 & 0.04 & - \\
\hline $\mathrm{Ni}(\mu \mathrm{M})$ & 0.147 & 0.137 & 0.156 & - \\
\hline As $(\mu \mathrm{M})$ & 0.042 & 0.04 & 0.047 & - \\
\hline $\operatorname{Se}(\mu \mathrm{M})$ & 0.094 & 0.144 & 0.166 & - \\
\hline $\mathrm{Cu}(\mu \mathrm{M})$ & 0.032 & $\begin{array}{l}0.04 \\
<8.90 \mathrm{E}-\end{array}$ & 0.045 & - \\
\hline $\mathrm{Cd}(\mu \mathrm{M})$ & $<8.90 \mathrm{E}-05$ & 05 & $<8.90 \mathrm{E}-05$ & - \\
\hline $\mathrm{Zn}(\mu \mathrm{M})$ & 0.028 & 0.056 & 0.139 & - \\
\hline $\operatorname{Co}(\mu \mathrm{M})$ & 0.006 & 0.005 & 0.007 & - \\
\hline $\operatorname{Cr}(\mu \mathrm{M})$ & 0.163 & 0.17 & 0.19 & - \\
\hline
\end{tabular}


1401 Table 2. $\delta \mathrm{D} \mathrm{H}_{2}, \delta^{13} \mathrm{C} \mathrm{CH}_{4}$, and $\delta \mathrm{D} \mathrm{CH}_{4}$ values for subsurface well water in Oman (NSHQ04 and 1402 NSHQ14), as well as hyperalkaline surface springs in Oman (Neal and Stanger, 1983), Zambales 1403 Ophiolite in the Philippines (Abrajano et al., 1990), Lost City Hydrothermal Vents

1404 (Proskurowski et al., 2006), the Precambrian Canadian Shield (Sherwood Lollar et al., 1993), 1405 and the Cedars Ophiolite in California (Morrill et al., 2013).

\begin{tabular}{llll} 
& $\delta \mathrm{D} \mathrm{H}_{2} \%$ & $\delta \mathrm{D} \mathrm{CH}_{4} \%$ & $\delta^{13} \mathrm{C} \mathrm{CH}_{4} \%$ \\
\hline NSHQ04_18m & -680 & -205 & 2.4 \\
NSHQ14_262m & -685 & -232 & 3 \\
Nizwa, Oman & -697 & & \\
Bahla, Oman & -699 & & \\
Huwayl Qufays, Oman & -699 & & \\
B'lad, Oman & -714 & & \\
Zambales Ophiolite & -581 & -122 & -7.34 \\
$\begin{array}{l}\text { Lost City Hydrothermal } \\
\text { Vents }\end{array}$ & -609 & -127 & -10 \\
$\begin{array}{l}\text { Precambrian Canadian } \\
\text { Shield }\end{array}$ & -619 & -284 & -29 \\
Cedars ophiolite & -40 to -50 & & -68
\end{tabular}


1408 Table 3. $\delta^{13} \mathrm{C}$ and $\delta^{18} \mathrm{O}$ values from carbonate found in drill cuttings. The unreported values are 1409 due to low carbonate concentrations.

\begin{tabular}{rrr} 
& $\boldsymbol{\delta}^{\mathbf{1 3}} \mathbf{C}_{\text {VPDB }}$ & $\boldsymbol{\delta}^{\mathbf{1 8}} \mathbf{O}_{\text {VPDB }}$ \\
\hline NSHQ14_17m & -7.05 & -7.73 \\
NSHQ14_70m & -- & -- \\
NSHQ14_140m & -4.75 & -11.07 \\
NSHQ14_262m & -4.69 & -11.49 \\
NSHQ04_120m & -- & -- \\
NSHQ04_180m & -- & -- \\
NSHQ04_303m & -1.48 & -10.99
\end{tabular}


1411 Table 4. Electron microprobe weight \% data for serpentine generations from well chip 1412 NSHQ04_180m corresponding to varying generations of serpentine identified with Raman 1413 spectroscopy. Numbers refer to various analysis spots on the well chip thin section.

\begin{tabular}{lllllll}
\hline \multicolumn{7}{c}{ Generation 1 and 2 chrysotile (04-gen1,2) } \\
\hline Sample & $\mathbf{3}$ & $\mathbf{5}$ & $\mathbf{6}$ & $\mathbf{9}$ & $\mathbf{1 0}$ & average \\
\hline $\mathbf{N a}_{\mathbf{2}} \mathbf{O}$ & 0.00 & 0.00 & 0.00 & 0.00 & 0.04 & 0.01 \\
$\mathbf{M g O}$ & 36.41 & 35.22 & 36.17 & 36.86 & 35.63 & 36.06 \\
$\mathbf{A l}_{\mathbf{2}} \mathbf{O}_{\mathbf{3}}$ & 0.40 & 0.99 & 0.82 & 0.31 & 0.85 & 0.67 \\
$\mathrm{SiO}_{\mathbf{2}}$ & 38.21 & 35.97 & 36.40 & 36.70 & 37.05 & 36.87 \\
$\mathbf{C a O}$ & 0.40 & 0.54 & 0.44 & 0.30 & 0.47 & 0.43 \\
$\mathbf{F e O}$ & 7.29 & 8.50 & 7.51 & 8.12 & 8.20 & 7.92 \\
$\mathbf{M n O}$ & 0.20 & 0.26 & 0.18 & 0.14 & 0.32 & 0.22 \\
$\mathbf{T i O}_{2}$ & 0.00 & 0.00 & 0.00 & 0.00 & 0.00 & 0.00 \\
$\mathbf{C r}_{2} \mathbf{O}_{3}$ & 0.09 & 0.61 & 0.51 & 0.00 & 0.42 & 0.33 \\
$\mathbf{T o t a l}$ & 82.99 & 82.09 & 82.03 & 82.43 & 82.99 & 82.51 \\
$\mathbf{M g} \#$ & 0.83 & 0.81 & 0.83 & 0.82 & 0.81 & 0.82 \\
\hline
\end{tabular}

Generation 3 lizardite intermixed with brucite (04-gen3)

\begin{tabular}{lllllll}
\hline Sample & $\mathbf{7}$ & $\mathbf{8}$ & $\mathbf{1 1}$ & $\mathbf{1 2}$ & $\mathbf{1 3}$ & average \\
\hline $\mathbf{N a}_{2} \mathbf{O}$ & 0.00 & 0.00 & 0.00 & 0.00 & 0.00 & 0.00 \\
$\mathbf{M g O}$ & 41.00 & 41.01 & 40.93 & 40.74 & 40.84 & 40.90 \\
$\mathbf{A l}_{2} \mathbf{O}_{3}$ & 0.00 & 0.00 & 0.08 & 0.14 & 0.03 & 0.05 \\
$\mathrm{SiO}_{2}$ & 33.58 & 34.51 & 35.74 & 34.63 & 34.54 & 34.60 \\
$\mathbf{C a O}$ & 0.06 & 0.07 & 0.12 & 0.15 & 0.12 & 0.10 \\
$\mathbf{F e O}$ & 8.12 & 7.41 & 6.07 & 6.13 & 7.24 & 6.99 \\
$\mathbf{M n O}$ & 0.00 & 0.00 & 0.11 & 0.09 & 0.15 & 0.07 \\
$\mathbf{T i O}_{2}$ & 0.00 & 0.00 & 0.00 & 0.00 & 0.00 & 0.00 \\
$\mathbf{C r}_{2} \mathbf{O}_{3}$ & 0.00 & 0.00 & 0.00 & 0.00 & 0.00 & 0.00 \\
$\mathbf{T o t a l}_{\mathbf{M g}}$ & 82.76 & 83.00 & 83.05 & 81.88 & 82.93 & 82.72 \\
$\mathbf{M g}$ & 0.83 & 0.85 & 0.87 & 0.87 & 0.85 & 0.85
\end{tabular}

